\title{
PEMBELAJARAN KETERAMPILAN BERBICARA TALKS AS INTERACION DALAM BAHASA INGGRIS PROFESI MELALUI GUIDED CONVERSATION DI STIPAR TRIATMA JAYA, BALI
}

\author{
Ni Putu Yunik Anggreni ${ }^{1}$, I Made Agung Rai Antara ${ }^{2}$ \\ Sekolah Tinggi IImu Pariwisata Triatma Jaya \\ yunikangreni73@gmail.com
}

\begin{abstract}
ABSTRAK
Keterampilan berbicara dalam bahasa Inggris adalah keterampilan seseorang untuk menyampaikan hasrat dan pemikirannya kepada siapa saja secara lisan dengan menggunakan bahasa Inggris. Keterampilan berbicara tersebut sulit berkembang jika tidak dilatih secara terus-menerus melalui interaksi antara pengguna bahasa Inggris. Hal ini bertujuan untuk meningkatkan keterampilan berbicara efektif mahasiswa sebagai pengguna Bahasa Inggris yaitu keterampilan berbicara yang dimiliki oleh seseorang jika ia dapat dan mampu menguasai masalah dan topik pembicaraan. Bagi mahasiswa perhotelan di Sekolah Tinggi Pariwisata (STIPAR) Triatma Jaya, konsentrasi Manajemen Akomodasi Perhotelan (MAP), kemampuan berbicara talk as interaction yang baik dan efektif merupakan keterampilan yang mutlak harus dikuasai. Keterampilan berbicara talk as interaction khususnya bagi seorang pramugraha yang memiliki tugas dalam memberikan pelayanan kepada tamu ketika menyiapkan dan menata kamar di hotel. Metode guided conversation diterapkan untuk meningkatan keterampilan berbicara talks as interaction yang baik dan efektif sesuai dengan SOP seorang pramugraha.

Penelitian ini penting dilakukan dengan tujuan untuk menjelaskan mekanisme penerapan metode guided conversation dalam pembelajaran keterampilan berbicara Talks as interaction dalam bahasa Inggris Profesi (BIP) pada mahasiswa Manajemen Akomodasi Perhotelan (MAP) di Sekolah Tinggi Pariwisata (STIPAR) Triatma Jaya, Badung Bali dan menghasilkan bahan ajar dalam pembelajaran Bahasa Inggris Profesi di Bidang Perhotelan. Populasi penelitian adalah seluruh peserta. Subyek penelitian adalah mahasiswa program studi Diploma III, Bidang Studi Manajemen Akomodasi Perhotelansemester 4, STIPAR Triatma Jaya, Badung, Bali tahun ajaran 2017/2018 dengan sample berjumlah 36 orang.

Hasil penelitian menunjukkan bahwa penerapan metode guided conversation dapat meningkatan kemampuan berbicara mahasiswa,yang dibuktikan dari hasil analisis data kualitatif dan kuantitatif. Secara kuantitatif terjadi peningkatan rerata dari setiap evaluasi tes. Hasil rerata pratindakan berkisar 71.44yang mengindikasikan bahwa kemampuan berbicara mahasiswa dengan kategori baik namun belum memenuhi kriteria kemampuan berbicara talk as interaction di departemen Tata Graha yang diperlukan oleh seorang pramugraha yang harus mampu berbicara lancar, baik, dan efektif. Setelah penerapan metode guided conversation pada siklus I nilai rerata mahasiswa meningkat menjadi 76.14 dan selanjutnya menjadi 81.86 pada siklus II yang mengindikasikan pencapaian sangat baik.
\end{abstract}

Kata Kunci: keterampilan berbicara, talk as interaction, metode guided conversation, Bahasa Inggris Profesi, Roomboy 
Jurnal Manajemen Pelayanan Hotel Akademi Komunitas Manajemen Perhotelan Indonesia (Anggreni \& Antara, halaman 45-73) Vol 3, No 1 Edisi Juni 2019

\section{PENDAHULUAN}

Keterampilan berbicara (speaking skill) dalam bahasa Inggris merupakan keterampilan seseorang untuk menyampaikan hasrat dan pemikirannya kepada siapa saja secara lisan dengan menggunakan bahasa Inggris. Keterampilan berbicara tersebut sulit berkembang jika tidak dipraktikan secara terus-menerus melalui interaksi antara mahasiswa, dan warga kampus lainnya. Hal ini bertujuan untuk meningkatkan penguasaan kosakata, menyempurnakan penempatan tekanan dan nada pada kalimat-kalimat yang digunakan, memperdalam kemampuan dalam penggunaan bahasa- bahasa ekspresi yang sesuai dengan topik dan situasi pembicaraan, dan melatih pendengaran sehingga mudah menangkap pesan dari lawan bicara.

Keterampilan berbicara yang baik dan efektif adalah keterampilan berbicara yang dimiliki oleh seseorang jika ia dapat dan mampu menguasai masalah dan topik pembicaraan. Seperti halnya mahasiswa perhotelan di Sekolah Tinggi Pariwisata (STIPAR) Triatma Jaya, konsentrasi Manajemen Akomodasi Perhotelan(MAP), memiliki keterampilan berbicara talk as interaction yang baik dan efektif merupakan hal yang sangat penting. Keterampilan berbicara talk as interaction digunakan pada saat seorang Roomboy memberikan pelayanan kepada tamu ketika menyiapkan dan menata kamar di hotel dan melaksanakan tugas dan tanggung jawab yang lain sebagai seorang Roomboy. Menjadi pelayan dituntut harus menguasai beberapa bahasa asing agar dapat berkomunikasi serta saling memahami apa yang dimaksudkan penutur dengan penerima tuturan tersebut (Anggayana \& Sari, 2018).

Beberapa kemampuan yang ikut dilibatkan dalam kegiatan berbicara talk as interaction antara lain, (1) membuka dan menutup percakapan, (2) memilih topik, (3) membuat percakapan-percakapan kecil/ringan, (4) berinteraksi antara satu dengan lainnya, (5) menggunakan gaya bahasa yang sesuai. (Richards, 2008:2128). Hal ini disebabkan bahasa adalah salah satu aspek terpenting dalam kehidupan kita serta tidak dapat dipisahkan dalam kegiatan sehari-hari manusia (Anggayana \& Sari, 2018).

Keterampilan berbicara talks as interaction sangat dibutuhkan pada saat menyapa tamu, baik melalui telepon ataupun bertemu dengan tamu secara langsung, memberikan informasi tentang fasilitas kamar dan cara penggunaannya, memberikan pesanan tamu, dan menangani keluhan tamu. Terkait dengan pernyataan di atas, maka mahasiswa dapat dikatakan memiliki kemampuan berbicara talks as interaction apabila memiliki kemampuan berbicara, seperti mampu mengungkapkan ide dan gagasan dalam berinteraksi dengan lawan bicara dengan menggunakan bahasa Inggris, menguasai kosakata-kosakata yang berhubungan dengan divisi akomodasi yang secara langsung membantu mahasiswa dalam memahami materi yang disajikan dalam mata kuliah keterampilan (MKK) yang harus ditempuh dalam Program Studi MAP. Setelah menguasai keterampilan berbicara, secara tidak langsung mereka akan memiliki keterampilan menulis. Menulis merupakan salah satu dari empat keterampilan berbahasa yang hendaknya dikuasai oleh mahasiswa (Lindawati, Asriyani, \& Anggayana, 2019). Walaupun, sebagai salah satu productive skill, keterampilan menulis dipandang sebagai keterampilan yang rumit untuk dipahami (Lindawati, Asriyani, \& Anggayana, 2019).

Kesulitan-kesulitan yang sering dialami oleh mahasiswa MAP STIPAR Triatma Jaya adalah menguasai dan melafalkan kosakata, menggunakan kosakata yang sesuai dengan SOP (standard operation procedure ) dan mengacu pada SKKNI dalam tatanan kalimat yang benar, memahami kalimatkalimat tersebut yang telah tersusun dalam sebuah percakapan (conversation) dan sekaligusberperan sebagai seorang Roomboy dengan penguasaan keterampilan berbicara yang baik dan 
Jurnal Manajemen Pelayanan Hotel Akademi Komunitas Manajemen Perhotelan Indonesia (Anggreni \& Antara, halaman 45-73) Vol 3, No 1 Edisi Juni 2019

efektif. Percakapan tersebut diawali dengan menyapa tamu (greeting the guests), menanyakan pesanan tamu (asking the guest order ), menanyakan nomor kamar dan nama tamu ( asking room number and name), mengulang pesanan ( repeating guest order ), memasuki kamar tamu ( entering the guest room ), memberikan pesanan ( giving the guest order ), menangani keluhan (handling compliant ), menyampaikan rasa terima kasih atas pesanan tamu (thanking to the guest).

Pembelajaran kosakata yang telah tersusun dalam sebuah percakapan yang terdapat dalam SOP tersebut telah disajikan dalam mata kuliah bahasa Inggris profesi (BIP), yaitu bahasa Inggris khusus yang disajikan dalam program studi MAP. Disamping itu penggunaan kosakatakosakata tersebut juga telah digunakan pada mata kuliah khusus ( MKK ) yang harus ditempuh oleh mahasiswa MAPselama masa perkuliahan, namun keterampilan berbicara talk as interaction yang baik dan efektif belum juga dimiliki oleh mahasiswa, sehingga lulusan yang terserap dalam industri pariwisata masih dalam jumlah yang sangat terbatas terutama oleh hotel-hotel yang berbintang dan bertaraf internasional.

Pelaksanaan uji kompetensi untuk okupasi roomboy sebagai salah satu okupasi yang terdapat pada departemen Kantor Depan dilaksanakan pada akhir perkuliahan di STIPAR Triatma Jaya, khususnya diujikan pada mahasiswa MAP semester 6 . Salah satu model evaluasi yang dilakukan adalah tes demontrasi ( praktik langsung ) sebagai roomboy untuk melihat keterampilan mahasiswa disamping tes lisan dan tulis untuk menggali pengetahuan mahasiswa. Oleh karena itu keterampilan berbicara bahasa Inggris mahasiswa sangat menentukan kompetensi mahasiswa untuk mendapatkan predikat kompeten dalam okupasi roomboy.

Berdasarkan permasalahan tersebut, berbagai usaha perbaikan telah dilakukan oleh para dosen untuk meningkatkan proses pembelajaran BIP dengan tujuan meningkatkan kemampuan para mahasiswa MAPuntuk dapat memiliki keterampilan berbicara talk as interaction yang baik dan efektif. Salah satu usaha yang dilakukan dengan menggunakan metode guided conversation. Dalam guide conversation mahasiswa diperlakukan sebagai subjek pembelajaran, secara aktif melakukan praktik-praktik berbahasa (bertanya dan menjawab dalam percakapan bahasa Inggris) bersama mahasiswa mahasiswa lainnya pada situasi tertentu. Dengan metode pembelajaran guided conversation pada akhirnya diharapkan mampu meningkatkan kemampuan mahasiswa dalam berbicarasehingga bermanfaat bagi mahasiswa yang akan memasuki dunia industri.

\section{PERMASALAHAN}

Rumusan masalah dari penelitian ini adalah sebagai berikut :

1. Bagaimanakah kemampuan mahasiswa MAP STIPAR Triatma Jaya dalam berbicara bahasa Inggris talks as interaction yang baik dan efektif sebelum dan setelah penerapan metode guided conversation?

2. Bagaimanakah mekanisme penerapan metode guided conversation tersebut pada mahasiswa MAP STIPAR Triatma Jaya?

\section{Tujuan Penelitan}

Tujuan dari penelitian ini adalah :

1. Untuk mengetahui dan menggambarkan kemampuan mahasiswa MAP STIPAR Triatma Jaya dalam berbicara bahasa Inggris talks as interaction yang baik dan efektif sebelum dan setelah penerapan metode guided conversation

2. Untuk menggambarkan mekanisme penerapan metode guided conversation tersebut pada mahasiswa MAP STIPAR Triatma Jaya

\section{Manfaat Penelitian}

Adapun manfaat dari penelitian ini adalah :

\section{Manfaat Teoritis}


Jurnal Manajemen Pelayanan Hotel Akademi Komunitas Manajemen Perhotelan Indonesia (Anggreni \& Antara, halaman 45-73) Vol 3, No 1 Edisi Juni 2019

Penelitian ini merupakan sebuah bentuk aplikasi ilmu linguistik yang diterapkan dalam bidang perhotelan khususnya pada departemen Tata graha ( housekeeping department).

\section{Manfaat Praktis}

Penelitian ini diharapkan bisa menjadi sebuah metode dalam pembelajaran bahasa Inggris di dunia perhotelan khususnya pengajaran BIP

\section{Kajian Teori}

\section{Faktor Keefektifan Berbicara}

Seorang pembicara dapat memiliki keterampilan berbicara secara efektif dan baik, jika ia dapat dan mampu memberikan kesan bahwa ia menguasai masalah yang dibicarakan. Penguasaan topik secara baik dan tepat akan menumbuhkan keberanian dan kelancaran. Selain menguasai topik, seorang pembicara harus berbicara (mengucapkan bunyi-bunyi bahasa) dengan jelas dan tepat. Pengucapan bunyi bahasa yang kurang tepat dapat mengalihkan perhatian pendengar. Kedua faktor tersebut harus diperhatikan oleh seorang pembicara untuk dapat menjadi pembicara yang baik dan efektif (Arsjad dan Mukti, 1988:17).

\section{Karakteristik Berbicara Bahasa Inggris Melalui Guided Conversation}

Kata guided, yang erat kaitannya dengan proses pembelajaran keterampilan berbicara bahasa Inggris adalah "membimbing dan memandu" mahasiswa dalam belajar. Untuk melakukan keterampilan berbicara bahasa asing seperti bahasa Inggris memang dirasakan sulit karena harus mengintegrasikan keterampilan lainnya (listening skill, reading skill, dan writing kill) ke dalam bentuk speaking yang baik. Dalam proses kegiatan keterampilan berbicara bahasa Inggris, mahasiswa justru harus melakukan lebih banyak komunikasi. Dalam hal ini membicarakan permasalahan yang sesuai dengan topik. Keuntungannya adalah semakin sering melakukan keterampilan berbicara semakin lancar pula refleksi berbicara (Zainil, 2010).

\section{Pembelajaran Melalui Guided Conversation \\ Dragsten (2005) menyatakan bahwa} bentuk proses pembelajaran yang dilakukan melalui guided conversation untuk mempelajari keterampilan berbicara bahasa Inggris yang sesuai dengan kondisi dan mempermudah mahasiswa untuk menguasainya.

Anggreni (2016) dalam penelitiannya yang berjudul "Peningkatan Keterampilan Berbicara Bahasa Inggris talks as transaction melalui guided conversation pada mahasiswa perhotelan, STIPAR Triatma Jaya memaparkan temuan bahwa penerapan metode guided conversation dapat meningkatan kemampuan berbicara bahasa Inggris talk as transaction yang dibuktikan dari hasil analisis data kualitatif dan kuantitatif. Hasil rerata setelah diterapkan guided conversation pada siklus I dan Siklus II mengindikasikan bahwa kemampuan berbicara mahasiswa dengan kategori sangat baik dan memenuhi kriteria kemampuan berbicara talk as transaction yang diperlukan oleh seorang pramusaji yang harus mampu berbicara lancar, baik, dan efektif.

\section{Keterampilan Berbicara Talks as Interaction}

Richard (2008: $21 \quad-\quad 28)$ mendifinisikan bahwa talks as Interaction adalah fungsi berbicara sebagai interaksi mengacu pada kegiatan percakapan yang biasa dilakukan dan berhubungan dengan fungsi sosial. Fokus utamanya adalah kepada si penutur dan bagaimana mereka menunjukkan diri mereka kepada orang lain. Bahasa tuturannya bisa formal ataupun berupa tuturan yang sering digunakan dalam percakapan sehari-hari. Beberapa kemampuan yang ikut dilibatkan dalam kegiatan berbicara sebagai sebuah interaksi, antara lain : (a) membuka dan menutup percakapan, (b) memilih topic, (c) membuat percakapan-percakapan kecil/ringan, (d) bergurau, ( e) menceritakan kejadian dan pengalaman pribadi, (f) dilakukan secara bergantian, (g) adanya interupsi/menyela percakapan, (h) bereaksi 
Jurnal Manajemen Pelayanan Hotel Akademi Komunitas Manajemen Perhotelan Indonesia (Anggreni \& Antara, halaman 45-73) Vol 3, No 1 Edisi Juni 2019

terhadap satu sama lain, dan (i) menggunakan gaya berbicara yang sesuai.

\section{Penilaian dan Evaluasi}

Trianto (2011: 61) memberikan definisi tes sebagai alat yang digunakan untuk mengukur tingkat ketuntasan belajar mahasiswa berupa nilai yang diperoleh dari pelaksanaan tes, sedangkan nontes adalah cara lain mengukur segala sesuatu yang tidak teramati dalam proses belajar mengajar. Alat pengukuran nontes, antara lain berupa pedoman observasi, skala sikap, daftar cek, catatan riwayat kelakuan, dan jaringan sisiomentrik. Pengalaman belajar dilakukan untuk mencapai tujuan (menguasai kompetensi tertentu ) dan evaluasi dilakukan untuk melihat sejauh mana kompetensi yang telah dilakukan oleh mahasiswa dalam bentuk hasil belajar yang diperlihatkan setelah mereka menempuh pengalaman belajar. Selain itu, dalam pengembangan kurikulum, evaluasi dilakukan dalam setiap tahap pengembangan kurikulum, yaitu mulai dari analisis kebutuhan, penetapan tujuan, penilaian, pengembangan bahan, hingga kegiatan pembelajaran ( Brown, 2002:28 ).

\section{Rubrik ( Scala Penilaian)}

Rubrik penilaian ialah skema penilaian deskriptif, yang digunakan sebagai patokan dalam menganalisis baik produk, proses, usaha maupun keberhasilan peserta didik. Rubrik ini digunakan untuk penilaian (judgment) kualitas dan dapat digunakan untuk mengevaluasi berbagai subjek ataupun kegiatan. Dalam penelitian ini rubrik yang digunakan adalah rubrik penilaian Analitik Jacobs (1981). Dalam

$$
\text { meninggalkan kelas atau }
$$

pekerjaannya; (2) tidak memerlukan biaya yang tinggi dan dapat dilakukan kapan saja; (3) hasil penelitian yang direncanakan dapat dirasakan; (4) bila treatment (perlakuan) dilakukan kepada responden, mereka dapatmerasakan hasilnya; dan (5) treatment yang dilakukan memberikan motivasi kepada subjek didik untuk menghasilkan perubahan sikap. Penelitian tindakan kelas sangat bermanfaat untuk memperluas kemampuan dan memperoleh pemahaman yang lebih tentang kelas, mahasiswa, dan diri sendiri sebagai dosen (Trianto, 2011: 18).

Lewin (dalam Suparno, 2008: 11) mengembangkan model spiral dalam penelitian tindakan yang kemudian menjadi sumber acuan dan banyak dikembangkan oleh para ahli lainnya. Adapun model yang dimaksud adalah (1) Refleksi, (2) Perencanaan, (3) Tindakan, dan (4) aksi berikutnya.

\section{METODE PENELITIAN \\ Tahap Penelitian}

Untuk mendapatkan refleksi awal, peneliti melakukan tes awal yang berbentuk tes pratindakan, yaitu mahasiswa beranggotakan tiga orang dalam satu grup melakukan percakapan, satu orang berperanan sebagai roomboy dan 2 orang berperanan sebagai tamu dan pada akhirnya setiap orang berperanan sebagai roomboy. Percakapan yang harus dipraktikkan secara role playing memiliki topik making up the guest room dengan situasi yang ditentukan, yaitu it is at 08.00 a.m., one couple in room 202 call to housekeeping office. They ask roomboy to make up their room at the time and they have a complaint about the bath tub in the bath room. Tes awal ini dimaksudkan untuk mengetahui kondisi mahasiswa sebenarnya tentang kemampuan berbicara mahasiswa dalam bahasa Inggris. Setelah diketahui gambaran awal, dilakukan persiapan penelitian, yaitu menyusun rencana pengajaran sekaligus menyusun bahan pembelajaran melalui tahap-tahapan guided conversation dan membuat instrumen penelitian.

Penelitian ini merupakan penelitian tindakan kelas (PTK) yang menggunakan dua siklus, yang berlangsung selama 150 menit ( 3 jam penyajian ). Pembagian siklus menjadi dua siklus, yaitu dalam satu siklus terdapat penyajian tiga kali pertemuan dan satu kali pertemuan sebagai refleksi. Setiap siklus terdiri atas empat tahap, yaitu (1) perencanaan, (2) tindakan, (3) observasi, dan (4) refleksi. 


\section{Lokasi Penelitian}

Penelitian ini dilakukan di STIPAR

Triatma Jaya Badung, Bali, tepatnya berlokasi di Jalan Kubu Gunung, Tegal Jaya, Dalung, Kuta, Badung, Bali. Sasarannya adalah mahasiswa Manajemen Akomodasi Perhotelan (MAP) STIPAR Triatma Jaya, jenjang studi diploma III, semester 4, dengan jumlah mahasiswa sebanyak 36 orang.

\section{Rancangan Penelitian}

Secara kualitatif, menggunakan rancangan deskriptif interpretatif dan secara kuantitatif menggunakan rancangan deskriptif kuantitif. Karakteristik kajian kualitatif adalah melibatkan kedua data sebagai sumber data langsung dan data deskriptif (Bogdan dan Biklen, 1992). Penelitian tindakan kelas ( PTK ) atau disebut juga dengan classroom action research (CAR), yang merupakan penelitian tindakan untuk tujuan memperbaiki mutu praktik pembelajaran di kelas (Burns, 2009: 6).

\section{Model Penelitian}

Penelitian ini merupakan penelitian tindakan kelas. Dalam penelitian tindakan kelas, terdapat empat aspek pokok, yaitu (1) penyusunan rencana, (2) tindakan, (3) observasi, dan (4) refleksi. Keempat aspek pokok tersebut dikaji secara bertahap dan sistematis yang diterapkan dalam dua siklus, yaitu siklus I dan siklus II. Dimana dalam setiap siklus disajikan tiga kali penyajian dan satu kali refleksi. Penelitian ini dilakukan dengan pendekatan kuantitatif dan kualitatif, sebagaimana dapat dilihat pada diagram di bawah ini.Berikut model penelitian kajian ini adalah : 


\section{Gambar 3.1 Model Penelitian}

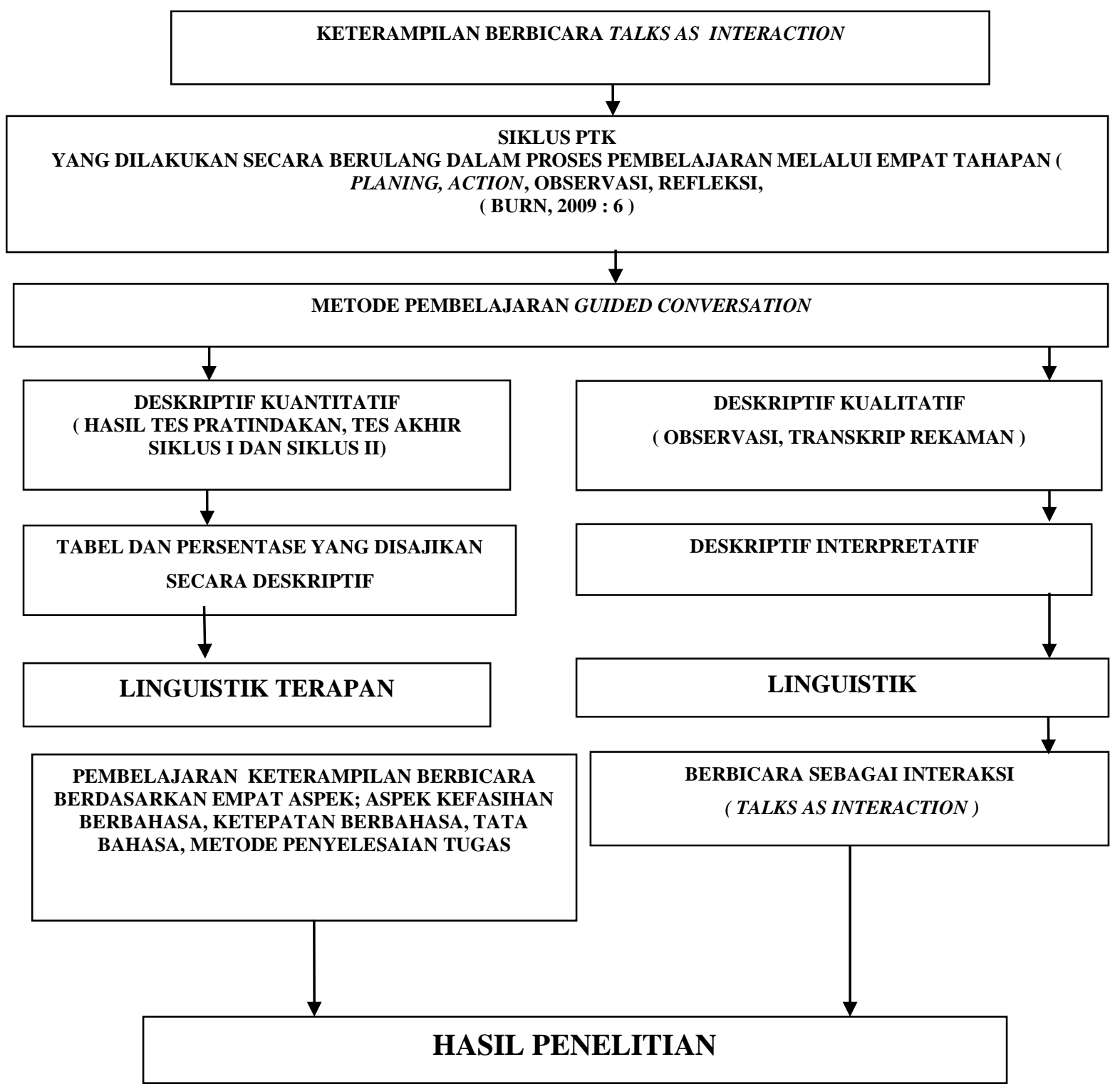




\section{Teknik Pengumpulan Data}

Teknik yang digunakan dalam pengumpulan data adalah teknik observasi (Sudaryanto, 1993:133). Teknik perekaman dan pencatatan juga diterapkan untuk membantu teknik observasi dimana salah satu kelebihan teknik rekaman adalah dapat mendengarkan rekaman percakapan berulang-ulang untuk mendapatkan penilaian yang objektif dari kemampuan berbicara mahasiswa. Untuk mendukung teknik rekaman juga dilakukan teknik pencatatan (field note ).Transrip rekaman merupakan data yang diperoleh dalam penelitian ini.

\section{HASIL PENELITIAN}

1. Kemampuan mahasiswa MAP STIPAR Triatma Jaya dalam berbicara bahasa Inggris talks as interaction yang baik dan efektif sebelum dan setelah penerapan metode guided conversation

Kemampuan berbahasa Inggris talks as interaction mahasiswa MAP STIPAR Triatma Jaya sebelum dan sesudah diterapkan metode guided conversationdapat dideskripsikan sebagai berikut :

Kemampuan mahasiswa berbicara talk as interactionsebelum menggunakan metode guided conversation

A Pratindakan

Pelaksanaan penelitian tindakan kelas dilaksanakan pada Program Studi Perhotelan, Jenjang Diploma III, Konsentrasi Manajemen Akomodasi Perhotelan ( MAP) di STIPAR Triatma Jaya tahun ajaran 2017/ 2018 dengan topik kemampuan mahasiswa berbicara talk as interaction sebagai seorang pramugraha

\section{Analisis Data}

Data kualitatif diperoleh dari transkrip rekaman pada setiap tindakan (treatment) siklus 1 dan siklus II. Data kuantitatif diperoleh dari data tes pratindakan, tes akhir siklus I, dan tes akhir siklus II. Kedua data ini dianalisis secara deskriptif. Analisis data kualitatif dilakukan di setiap akhir siklus yang dilakukan. Hasil pratindakan, siklus I, dan siklus II dianalisis secara deskriptif.

Adapun rumus dari analisis data secara kuantitaif adalah

\begin{tabular}{|c|}
$\mathbf{X}=\underline{\boldsymbol{\Sigma X}}$ \\
$\mathbf{N}$
\end{tabular}

Keterangan :

$\begin{array}{lll}\text { Mean }(\mathrm{X}) & : & \text { rerata siswa } \\ \mathrm{X} & : & \text { hasil siswa } \\ \mathrm{N} & : & \text { jumlah siswa } \\ \Sigma & : & \text { jumlah keseluruhan } \\ \text { menggunakan } & \text { metode guided }\end{array}$
conversation.Pelaksanaan pratindakan dilakukan pada Senin, 4 Juni 2018 diikuti oleh 36 orang mahasiswa. Pada pelaksanaan pratindakan ini metode guided conversation belum diterapkan. Dalam proses kegiatan pratindakan ini, peneliti bertindak sebagai pengamat dan menuliskan hasil pengamatan pada lembaran observasi yang telah disiapkan.

\section{B. Hasil Pratindakan secara Kuantitatif dan Kualitatif \\ Pelaksanaan pratindakan dilakukan} pada mahasiswa Program Studi Perhotelan, Jenjang Diploma III, Konsentrasi Manajemen Akomodasi Perhotelan ( MAP) di STIPAR Triatma Jaya tahun ajaran 2017/ 2018. Kegiatan ini terdiri atas dua bagian analisis, yaitu analisis kuantitatif dan analisis kualitatif.

$\begin{array}{llrr}\text { 1. Analisis } & \text { Kuantitatif } & \text { pada } \\ \text { Pratindakan } & & \\ \text { Berdasarkan } & \text { hasil } & \text { observasi } \\ \text { langsung yang dilakukan } & \text { terhadap } \\ \text { mahasiwa } & \text { Program Studi } & \text { Perhotelan, } \\ \text { Jenjang } & \text { Diploma III, Konsentrasi } & \text { Kons } \\ \text { Manajemen Akomodasi Perhotelan ( MAP) }\end{array}$


Jurnal Manajemen Pelayanan Hotel Akademi Komunitas Manajemen Perhotelan Indonesia (Anggreni \& Antara, halaman 45-73) Vol 3, No 1 Edisi Juni 2019

di STIPAR Triatma Jaya tahun ajaran 2017/ 2018, ketika dilakukan tes awal dan dari catatan yang didapatkan dari lembar observasi dapat disampaikan bahwa penyampaian materi ajar yang dilakukan oleh dosen kurang efektif karena hanya dilakukan dengan metode ceramah. Dalam penyampaian materi pembelajaran dengan metode ini, mahasiswa terlihat kurang antusias menerima perkuliahan. Hal ini disebabkan karena belum terciptanya peran serta mahasiswa secara aktif.

Penyajian mata kuliah khusus keahlian ( MKK ) pada jurusan MAP bertujuan untuk saling mendukung kemampuan mahasiswa untuk menguasai mata kuliah BIP( Bahasa Inggris Profesi ) dan MKK tersebut yang merupakan kunci keberhasilan mahasiswa dalam berkompetisi untuk mendapatkan pekerjaan di dunia perhotelan dan pariwisata setelah menamatkan perkuliahan di STIPAR Triatma Jaya.Meskipun mahasiswa MAP telah diberikan pembelajaran BIP dan MKK, namun kompetensi bahasa Inggris mahasiswa masih berada dalam level sedang dengan rerata kelas $71,44 . \mathrm{Hal}$ ini dapat dibuktikan dengan hasil rekaman percakapan mahasiwa, yaitu hanya 3 orang mahasiswa yang mampu memperoleh nilai rerata dengan kategori $(A: 80-100), 18$ mahasiswa dengan nilai ( $B: 70-79), 15$ orang dengan nilai ( $C: 57-69$ ).

Pada kegiatan pratindakan dosen hanya menyampaikan sebuah contoh percakapan seorang pramugraha dengan topik"taking guest order" tanpa menerapkan metode guided conversation. Selanjutnya mahasiswa menuliskan sebuah percakapan sesuai dengan judul yang ditentukan, kemudian memeragakannya dengan pasangan masing- masing.Hasil percakapan mahasiswa secara kuantitatif dapat dilihat pada tabel di bawah ini :

Tabel 5.1 Hasil Belajar pada Pratindakan

\begin{tabular}{|l|l|l|l|l|l|l|}
\hline \multirow{2}{*}{ NO } & \multirow{2}{*}{ NAMA MAHASISWA } & \multicolumn{2}{l}{ NILAI } & \multirow{2}{*}{ SKOR } \\
\cline { 3 - 6 } & & 1 & 2 & 3 & 4 & \\
\hline 1. & Agnesia M. A & 17 & 14 & 18 & 31 & 80 \\
\hline 2. & Adi arta Y & 12 & 12 & 17 & 30 & 71 \\
\hline 3. & Andre K. A. & 12 & 12 & 11 & 29 & 64 \\
\hline 4 & Anik W. & 10 & 12 & 14 & 30 & 66 \\
\hline 5 & Ari Susila & 6 & 10 & 12 & 27 & 55 \\
\hline 6 & Ariska M. & 14 & 15 & 16 & 28 & 73 \\
\hline 7 & Aulia Nugraheni & 14 & 14 & 16 & 29 & 73 \\
\hline 8 & Bagus Restu A & 17 & 12 & 14 & 27 & 70 \\
\hline 9 & Darmayana & 17 & 12 & 17 & 31 & 77 \\
\hline 10 & Elza Erlinda S & 17 & 16 & 18 & 31 & 82 \\
\hline 11 & Eva Dhodo & 15 & 14 & 17 & 27 & 73 \\
\hline 12 & Giri Sandi P. & 11 & 12 & 15 & 29 & 67 \\
\hline 13 & Gita A. & 12 & 14 & 12 & 30 & 68 \\
\hline 14 & Indra P. & 11 & 12 & 15 & 29 & 67 \\
\hline 15 & Mira Sari A. & 15 & 15 & 17 & 32 & 79 \\
\hline 16 & Pelan Suaba & 14 & 17 & 17 & 31 & 79 \\
\hline 17 & Rezha F. & 12 & 12 & 17 & 29 & 70 \\
\hline 18 & Ricky Adi P. & 10 & 12 & 17 & 29 & 68 \\
\hline 19 & Ruditayasa & 10 & 12 & 17 & 29 & 68 \\
\hline 20 & Abdi W & 15 & 14 & 15 & 32 & 76 \\
\hline 21 & Abi W P & 12 & 12 & 15 & 29 & 68 \\
\hline 22 & Adi Sugiartawan & 10 & 15 & 17 & 29 & 71 \\
\hline 23 & Adi S. D & 12 & 14 & 17 & 29 & 72 \\
\hline 24 & Arimbawa Dewa & 11 & 12 & 15 & 31 & 69 \\
\hline & & & & & & \\
\hline
\end{tabular}


Jurnal Manajemen Pelayanan Hotel Akademi Komunitas Manajemen Perhotelan Indonesia (Anggreni \& Antara, halaman 45-73) Vol 3, No 1 Edisi Juni 2019

\begin{tabular}{|l|l|l|l|l|l|l|}
\hline 25 & Arya Dinata & 10 & 12 & 15 & 32 & 69 \\
\hline 26 & Budi Ariawan & 10 & 14 & 15 & 30 & 69 \\
\hline 27 & Eka Diana I Putu & 12 & 14 & 17 & 29 & 72 \\
\hline 28 & Juniarta & 10 & 12 & 15 & 29 & 66 \\
\hline 29 & Mediana I Kadek & 10 & 16 & 15 & 27 & 68 \\
\hline 30 & Nova Artana & 15 & 14 & 17 & 29 & 75 \\
\hline 31 & Pranata & 12 & 14 & 17 & 25 & 68 \\
\hline 32 & Raditya & 15 & 12 & 17 & 27 & 71 \\
\hline 33 & Sedana & 15 & 14 & 16 & 30 & 75 \\
\hline 34 & Tonny D & 15 & 16 & 17 & 29 & 77 \\
\hline 35 & Wahyu & 15 & 15 & 16 & 30 & 76 \\
\hline 36 & Riski A & 17 & 15 & 17 & 31 & 80 \\
\hline & Rerata & $\mathbf{1 2 . 8 3}$ & $\mathbf{1 3 . 4 4}$ & $\mathbf{1 5 . 8 3}$ & $\mathbf{2 9 . 3 3}$ & $\mathbf{7 1 . 4 4}$ \\
\hline
\end{tabular}

Keterangan : (1) Kefashian Berbahasa, (2) Kosakata, (3), Ketepatan Berbahasa (Tata Bahasa ), (4) Metode Penyampaian Pesan

Nilai tertinggi 82 diraih oleh 1 orang mahasiswa, dimana 3 atau $8.3 \%$ mahasiswa yang mampu memperoleh nilai rerata dengan kategori $(A: 80-100), 18$ atau $50 \%$ mahasiswa dengan nilai ( $B: 70-$ 79 ), 15 atau $41.6 \%$ mahasiswa dengan nilai ( C : $57-69$ ). Dengan demikian dari prosentase ini dapat disimpulkan bahwa kemampuan berbicara mahasiswa yang

Tabel 5.2 Nilai Mahasiswa Berdasarkan Empat Aspek Penilaian (Pratindakan)

\begin{tabular}{|c|c|c|c|c|c|}
\hline \multirow[t]{2}{*}{ Nilai } & $\begin{array}{l}\text { Kefasihan } \\
\text { Berbahasa }\end{array}$ & Kosakata & Tata Bahasa & Nilai & $\begin{array}{c}\text { Metode Penyele } \\
\text { saian Tugas }\end{array}$ \\
\hline & 1 & 2 & 3 & & 4 \\
\hline $\begin{array}{l}18-20 \\
\text { (sangat baik) }\end{array}$ & 0 & 0 & 2 & $\begin{array}{c}40--38 \\
\text { ( sangat baik) }\end{array}$ & 0 \\
\hline $\begin{array}{l}15-17 \\
\text { (baik) }\end{array}$ & 13 & 9 & 29 & $\begin{array}{c}35--37 \\
\text { (baik) }\end{array}$ & 0 \\
\hline $\begin{array}{l}12-14 \\
\text { (cukup baik) }\end{array}$ & 11 & 26 & 4 & $\begin{array}{c}32 \text {-- } 34 \\
\text { (cukup baik) }\end{array}$ & 3 \\
\hline $\begin{array}{l}\text { 6-11 } \\
\text { (kurang) }\end{array}$ & 12 & 1 & 1 & $\begin{array}{c}29-31 \\
\text { (kurang) }\end{array}$ & 27 \\
\hline $\begin{array}{l}1-5 \\
\text { (sangat } \\
\text { kurang) }\end{array}$ & 0 & 0 & 0 & $\begin{array}{c}25-27 \\
\text { (sangat kurang) }\end{array}$ & 6 \\
\hline
\end{tabular}

Mahasiswa memiliki kemampuan baik dalam kefasihan berbicara talks as interaction dimana sebanyak 13 orang berada pada skor 15-17 ( baik ). Kemudian sebanyak 11 orang memiliki kemampuan cukup baik (12-14) dalam kefasihan berbicara. Sebanyak 12 orang memiliki kemampuan kurang dalam aspek kefasian berbicara.

Kemampuan mahasiswa dilihat dari aspek ketepatan penggunaan kosa kata adalah sebanyak 9 orang memiliki kemampuan baik (15-17). Sebanyak 26 mahasiswa memiliki kemampuan cukup baik ( 12-14 ) dalam ketepatan penggunaan efekti yang diperlukan dunia industry perhotelan masih tergolong rendah. Lebih terperinci, nilai mahasiswa berdasarkan empat aspek penilaian dapat dilihat pada tabel di bawah ini. kosa kata. Sedangkan hanya 1 mahasiswa yang tergolong kurang keampuannya dalam ketepatan penggunaan kosa kata.

Kemampuan mahasiswa dalam ketepatan berbahasa dapat diuraikan sebagai berikut yaitu terdapat 2 orang maahsiswa yang memiliki kemampuan sangat baik dalam ketepatan berbahasa, sebanyak 29 orang tergolong berkemampuan baik dalam ketepatan berbahasa, 4 orang tergolong berkemampuan cukup baik dalam ketepatan berbahasa dan hanya 1 orang yang memiliki kemampuan kurang dalam ketepatan berbahasa. 
Jurnal Manajemen Pelayanan Hotel Akademi Komunitas Manajemen Perhotelan Indonesia (Anggreni \& Antara, halaman 45-73) Vol 3, No 1 Edisi Juni 2019

Kemampuan dalam aspek penyelesaian tugas dapat diuraikan sebagai berikut yaitu sebanyak 3 orang mahasiswa yang tergolong berkemampuan cukup, 27 orang tergolong berkemampuan kurang dan 6 orang termasuk berkemampuan sangat kurang dalam aspek penyelesaian tugas.

\section{Analisis Kualitatif pada Pratindakan}

Penilaian pada kemampuan berbicara "taking the guest order in housekeeping department" dapat dilakukan dengan menggunakan rubrik penilaian yang diadaptasi dari Jacob (1981) yang membagi kriteria penilaian menjadi empat aspek yaitu (1) kefasihan berbahasa, (2) kosakata, (3) tata bahasa, dan (4) metode penyelesaian tugas. Pada aspek kefasihan berbahasa kemampuan berbicara mahasiswa dianalisis berdasarkan dimensi (1) pelafalan kosakata, (2) kesalahan tekanan dan pola intonasi, (3) pengaruh bahasa ibu, (4) pandangan kepada lawan bicara, (5) sikap tenang, wajar, dan tidak kaku, (6) gerak gerik dan mimik yang tepat, dan ( 7) kelancaran.

Aspek kosakata dianalisis berdasarkan dimensi (1) penggunaan kosakata yang sesuai dengan topik percakapan, (2) penempatan kosa kata yang sesuai dengan ekpressi yang mendukung topik percakapan, dan (3) kemampuan menjelaskan makna kosa kata yang digunakan dalam percakapan.

Aspek tata bahasa dianalisis berdasarkan dimensi (1) kohesi gramatikal, yang terdiri atas referensi, yaitu hubungan pengacuan suatu unsur dengan unsur lain baik yang muncul sebelumnya, sesudahnya, maupun di luar teks ; substitus,i yaitu penyulihan suatu kata atau kelompok kata oleh kata lain untuk tujuan tertentu ; dan ellipsis, yaitu pelesapan suatu kata atau bagian dari kalimat yang dilakukan untuk kepaduan wacana (Cutting,
2002), dan (2) kesalahan penggunaan bentuk tenses, kesalahan penggunaan gerund, kesalahan penggunaan verb.yangmenyusun percakapan tersebut.

Aspek yang terakhir adalah aspek metode penyelesaian tugas. Aspek ini dianalisis berdasarkan dimensi (1) percakapan dibangun oleh kalimat-kalimat yang sesuai dengan topik yang dibicarakan, (2) urutan penyampaian percakapan terstruktur dengan baik, (3) konteks, yang merupakan konsep yang dinamis, bukan konsep yang statis, artinya konteks dipahami sebagai situasi yang selalu berubah, yang membuat partisipan dalam proses komunikasi dapat berinteraksi dan dengan konteks pula ekspresi bahasa dapat digunakan dalam berinteraksi ( Mey, 2001: 39), (4) koherensi, yaitu kepaduan suatu wacana yang ditunjukkan oleh perangkat kontekstual suatu teks, yang berupa situasi yang melatarbelakangi teks sehingga teks tersebut dapat dipahami sebagai wacana yang padu (Paltridge, 2000: 139).

\section{A. Analisis Tata Bahasa Inggris Ketepatan Berbahasa Inggris )}

Pada aspek tata bahasa dianalisis dalam dua dimensi yaitu (1) kohesi gramatikal, yang terdiri atas referensi yaitu hubungan pengacuan suatu unsur dengan unsur lain baik yang muncul sebelumnya, sesudahnya, atau bahkan di luar teks; substitusi yaitu penyulihan suatu kata atau kelompok kata oleh kata lain untuk tujuan tertentu ; dan ellipsis yaitu pelesapan suatu kata atau bagian dari kalimat yang dilakukan untuk kepaduan wacana ( Cutting, 2002 ), (2) Kesalahan dalam klausa dan struktur kalimat seperti penggunaan bentuk tenses, kesalahan penggunaan gerund, kesalahan penggunaan verb, kesalahan penggunaan pronominal, kesalahan penggunaan nomina kalimat yang menyusun percakapan tersebut. 
Jurnal Manajemen Pelayanan Hotel Akademi Komunitas Manajemen Perhotelan Indonesia (Anggreni \& Antara, halaman 45-73) Vol 3, No 1 Edisi Juni 2019

Percakapan 1

\begin{tabular}{|l|l|}
\hline \multicolumn{1}{|c|}{ Pramugraha } & \multicolumn{1}{c|}{ Percakapan } \\
\hline Pramugaraha & Good morning housekeeping. Can I helping you ? \\
\hline Tamu & Good morning. I'd like some more tissue, please \\
\hline Pramugraha & Ok sir. Could I have you room number and you name? \\
\hline Tamu & Yes, This is 1110 \\
\hline Pramugraha & I'm sorry. That is room 1110? \\
\hline Tamu & Yes, That's right \\
\hline Pramugraha & And you name please Sir ? \\
\hline Tamu & This is Mr. Andrew \\
\hline Pramugraha & Ok Mr. Andrew \\
\hline Tamu & Ok thank you \\
\hline
\end{tabular}

Dari percakapan diatas dapat dianalisis kesalahan dari 4 aspek penilaian sebagai berikut

Kesalahan Ketepatan Berbahasa ( Tata Bahasa Inggris ) Tabel 5.3 Kesalahan Tata Bahasa Percakapan

\begin{tabular}{|c|l|l|l|}
\hline NO & \multicolumn{1}{|c|}{$\begin{array}{c}\text { Dimensi } \\
\text { Kesalahan }\end{array}$} & \multicolumn{1}{c|}{$\begin{array}{c}\text { Percakapan Mahasiswa } \\
\text { Perbaikan }\end{array}$} \\
\hline 1 & $\begin{array}{l}\text { Ellipsis : yaitu } \\
\text { pelesapan suatu kata } \\
\text { atau bagian dari } \\
\text { kalimat yang dilakukan } \\
\text { untuk kepaduan } \\
\text { wacana (Cutting, 2002 } \\
; 2)\end{array}$ & $\begin{array}{l}\text { Pramugraha: Could I have you room } \\
\text { number and you name? }\end{array}$ & $\begin{array}{l}\text { Pramugraha: Could I have } \\
\text { your name and room number } \\
\text { please ? }\end{array}$ \\
\hline 2 & $\begin{array}{l}\text { Klausa dan struktur } \\
\text { kalimat }\end{array}$ & $\begin{array}{l}\text { Pramugraha : Could I have you name } \\
\text { please? } ?\end{array}$ & $\begin{array}{l}\text { Pramugraha : Could I have } \\
\text { your name please ? } \\
\text { Pramugraha : Could I help } \\
\text { you ? }\end{array}$ \\
\hline
\end{tabular}

Cutting , 2002 : 2 menyatakan bahwa Ellipsis adalah Pelesapan suatu kata atau bagian dari kalimat yang dilakukan untuk kepaduan wacana.Penggabungan dua klausa baik secara koordinatif maupun subordinatif dapat menimbulkan terdapatnya dua unsur yang sama dalam satu kalimat. Hal ini menyebabkan ketidakefektifan dalam aspek kebahasaan, karena informasi yang terkandung menjadi ganda. Untuk menanggulangi hal tersebut, maka salah satu unsur yang sama itu harus dilesapkan ( ellipsis ).

Pada klausa diatas terjadi pelesapan objek yaitu your name and your room number. Kalimat ini dapat mengalami elipsis yang ebih tepat yaitu Could I have your name and room number?
Kesalahan pada struktur kalimat juga terjadi pada kalimat Could I have you name please? Seharusnya digunakan kata ganti your name. Kesalahan struktur kalimat juga terjadi pada kalimat could I helping you ? Dalam kalimat ini seharusnya digunakan kata kerja bentuk pertama yaitu help bukan helping karena struktur kalimat tersebut pada tenses simple present tense.

\section{Kesalahan Pengunaan Kosa Kata Bahasa Inggris \\ Hasil tes pada pratindakan menunjukkan terjadinya kesalahan penggunaan kosakata bahasa Inggris. Hal tersebut muncul karena kurangnya pemahaman yang benar terhadap makna suatu kata dan kesulitan yang dialami pramugraha untuk menemukan sinonimi kata-kata yang digunakan dalam percakapan tersebut. Kesalahan yang}


Jurnal Manajemen Pelayanan Hotel Akademi Komunitas Manajemen Perhotelan Indonesia (Anggreni \& Antara, halaman 45-73) Vol 3, No 1 Edisi Juni 2019

dilakukan pramugraha dapat diuraikan sebagai berikut : Tamu : Good morning. I'd like some more tissue, please; Pramugraha :Ok sir. Could I have you room number and you name ?. Pada kalimat ini kesalahan penggunaan kata "ok" dilakukan oleh pramugraha. Kosa kata yang seharusnya digunakan adalah certainly, of couse, alright. Kosa kata ini menunjukkan kesantunan yang lebih tinggi daripada penggunaan kosakata ' OK"

Kesalahan kedua pada kalimat, pramugraha : Ok Mr. Andrew ; tamu : Thank you. Pada struktur kalimat yang diujarkan pramugraha terdapat kesalahan penggunaan kosakata Ok Mr. Andrew. Seharusnya bahasa ekpresi pada kalimat penutup percakapan adalah thank you Mr. Andrew. I'll come to your room soon.

\section{Kesalahan Dalam Kefasihan Berbahasa}

Dalam kalimat tanya yang menggunakan kata tanya ( question words ), penempatan intonasi ditempatkan pada kata tanya yang digunakan dan kata yang terletak pada akhir kalimat dengan a fall tone atau tekanan menurun (McCharty, 2000:106). Berdasarkan pendapat tersebut dapat disimpulkan bahwa meskipun terdapat kesalahan penempatan tekanan dan intonasi pada beberapa kosakata pada percakapan mahasiswa, namun pesan tersampaikan kepada lawan berbicara.

Pandangan pembicara hendaknya diarahkan kepada semua pendengar dan pendengar harus dilibatkan dan diperhatikan (Arsjad dan Mukti, 1988:21). Berdasarkan pendapat tersebut dapat dikatakan bahwa pandangan pramugraha belum diarahkan kepada lawan bicara. Selanjutnya dimensi sikap, tenang, wajar, dan tidak kaku merupakan dimensi yang juga berperanan penting dalam keberhasilan sebuah pembicaraan. Pramugrahamasih bersikat kurang tenang dan gugup, dimana sikap ini muncul karena penguasaan materi, situasi, dan tempat belum baik.Keefektifan berbicara pramugraha juga belum tercapai. Hal ini disebabkan oleh gerak-gerik dan mimik pramugraha belum tepat dan belum wajar.
Hal ini membuat perhatian pendengar belum tertuju pada pramugraha dan pesan yang disampaikan belum tuntas dipahami.

\section{Kesalahan Dalam Aspek Metode Penyelesaian Tugas \\ Hasil tes pada pratindakan} menunjukkan terjadinya kesalahan metode penyampaian pesan bahasa Inggris dalam percakapan mahasiswa yang berperanan sebagai pramugraha. Hal tersebut disebabkan oleh kurangnya pengetahuan pramugraha dalam membangun kalimat kalimat yang sesuai dengan topik yang dibicarakan, urutan penyampaian pesan dan penyelesaian tugas sesuai dengan topik pembicaraan "taking guest order in the housekeeping department". Hal ini berarti percakapan yang tersusun belum sesuai dengan SOP pramugraha dalam mengambil pesanan tamu melalui telepon maupun di kamar tamu di sebuah hotel. Selain itu belum terwujud percakapan dengan kalimat-kalimat yang disusun oleh bahasabahasa ekspresi yang berhubungan dengan topik percakapan. Bahasa ekspresi yang terdapat dalam percakapan harus terdiri atas (1) greeting, (2) introducing his/her self, (3) offering a help, (5) asking the guest name and room number, (6) asking the guest order (7) checking and repeating the guest order, (9) closing conversation by saying thank you

Mey (2001: 137) menyebutkan bahwa wujud penggunaan bahasa tersebut dapat dilihat dari dua aspek, yaitu (1) aspek isi dan (2) aspek formal percakapan. Aspek isi yaitu aspek yang memperhatikan hal-hal, seperti topik apa yang didiskusikan dalam percakapan; bagaimana topik disampaikan dalam percakapan: apakah secara eksplisit, melalui presuposisi, atau diimplisitkan dengan berbagai macam cara; jenis topik apa yang mengarah pada topik lain, dan apa alasan yang melatarbelakangi hal semacam ini terjadi. Aspek formal percakapan, yaitu organisasi topik dalam percakapan dan bagaimana topik dikelola, baik disampaikan dengan cara terbuka maupun dengan manipulasi secara tertutup: 
Jurnal Manajemen Pelayanan Hotel Akademi Komunitas Manajemen Perhotelan Indonesia (Anggreni \& Antara, halaman 45-73) Vol 3, No 1 Edisi Juni 2019

biasanya dalam bentuk tindak ujar tak langsung; bagaimana percakapan bekerja; aturan-aturan apa yang dipatuhi; dan bagaimana sequencing 'keberurutan' dapat dicapai (memberikan dan memperoleh giliran atau mekanisme turn-taking, jeda, interupsi, overlap, dll.). Berdasarkan pendapat di atasa maka kesalahan yang dilakukan pramusaji dapat ditampilkan dalam percakapan di bawah ini

Kesalahan metode penyelesaian tugas yang terjadi dapat diuraikan sebagai berikut :

\section{Aspek isi}

Pada kalimat (1), ditemukan kesalahan pada pemarkah kohesi yang digunakan, yaitu dalam penggunaan introducing her/hiself untuk membangun sebuah susunan greeting yang lengkap, pramugraha : good morning housekeeping. Can I helping you ?. Seharusnya, pramugraha ; good morning housekeeping. Eva's speaking. Can I help you please ?.Namun, partisipan ( pramugrahadantamu) dalam percakapan tersebut saling memahami. Pembaca juga dapat memahami percakapan di atas, yaitu ketika pramugraha memberikan salam dan menerima telepon tamu yang menelepon ke housekeeping office. Selanjutnyapramugaraha juga menanyakan nama dan nomor kamar tamu tersebut, pramugraha :Ok sir. Could I have you room number and you name ?. Tamu memberikan respon dengan menjawab, tamu : yes, This is 1110 Dalam aturan gramatikal tidak terdapat relasi antara ujaran pramusaji dan tamu. Meskipun susunan kalimat tidak lengkap secara gramatikal namun pramugraha dapat memahami bahwa keadaan tamu membutuhkan pelayanan di kamar yaitu minta dibawakan gantungan baju ( coat hanger ). Pada dasarnya pramugraha dan tamu dapat saling memahami karena adanya pengetahuan bersama tentang pelayanan pesanan fasilitas kamar di sebuah hotel. Oleh sebab itu, dapat dikatakan bahwa percakapan di atas merupakan wacana yang koheren dan memiliki aspek isi

\section{Aspek formal percakapan}

Topik percakapan adalah taking guest order at hosekeeping department. Berdasarkan topik yang ditentukan ditemukan kesalahan pada aspek formal yaitu topikdan situasi belum dikelola dengan baik dan lengkap. Artinya, terlihat percakapan dibangun dari menyapa tamu ( greeting),menanyakan nama dan nomor kamar tamu.Selanjutnya urutan-urutan berikutnya yang sesuai dengan topik dan situasi yang ditentukan belum juga terkelola dengan baik dan lengkap.Bahasa-bahasa ekspresi yang ditentukan sesuai dengan aturan SOP pramugraha, Dengan demikian, percakapan tersebut belum memenuhi aspek formal percakapan yang utuh dan terpadu.

\section{Kemampuan mahasiswa berbicara talk as interactionsesudah menerapkan metode guided conversation}

Kemampuan mahasiswa berbicara talks as interaction sebagai pramugraha sesudah menerapkan metode guided conversation pada program studi MAP STIPAR Triatma Jaya dapat diuraikan menjadi 2 yaitu pada siklus I dan siklus II

\section{Kemampuan Berbicara Mahasiswa pada} Siklus I

Hasil belajar tes akhir siklus I dibandingkan dengan hasil belajar tes pratindakan untuk mengetahui seberapa jauh peningkatan kemampuan berbicara yang dimiliki oleh mahasiswa.

\section{Hasil Siklus I Secara Kuantitatif}

Penyampaian materi menggunakan metode guided conversation pada pembelajaran bahasa Inggris yang diterapkan pada mahasiswa MAP STIPAR Triatma Jaya menunjukkan bahwa penerapan metode guided conversation adalah efektif. Hal ini dibuktikan dengan peningkatan nilai yang dihasilkan mahasiswa pada siklus I. Hasil rekaman percakapan mahasiswa mengalami peningkatan, baik dalam kefasihan berbicara, ketepatan penggunaan kosakata, 
Jurnal Manajemen Pelayanan Hotel Akademi Komunitas Manajemen Perhotelan Indonesia (Anggreni \& Antara, halaman 45-73) Vol 3, No 1 Edisi Juni 2019

penerapan tata bahasa, maupun metode penyelesaian tugas. Dari keempat aspek penilaian tersebut yang lebih jelas terlihat peningkatannya adalah pada aspek metode penyelesaian tugas.

Hasil Belajar pada Siklus I

\begin{tabular}{|c|c|c|c|c|c|c|}
\hline \multirow[t]{2}{*}{$\mathrm{NO}$} & \multirow[t]{2}{*}{ NAMA MAHASISWA } & \multicolumn{4}{|l|}{ NILAI } & \multirow[t]{2}{*}{ SKOR } \\
\hline & & 1 & 2 & 3 & 4 & \\
\hline 1. & Agnesia M. A & 9 & 12 & 18 & 33 & 72 \\
\hline 2. & Adi arta $Y$ & 17 & 16 & 18 & 34 & 85 \\
\hline 3. & Andre K. A. & 9 & 10 & 12 & 30 & 61 \\
\hline 4 & Anik W. & 11 & 11 & 16 & 33 & 71 \\
\hline 5 & Ari Susila & 11 & 17 & 12 & 32 & 72 \\
\hline 6 & Ariska M. & 12 & 14 & 18 & 36 & 80 \\
\hline 7 & Aulia Nugraheni & 14 & 14 & 16 & 29 & 73 \\
\hline 8 & Bagus Restu A & 17 & 14 & 18 & 27 & 76 \\
\hline 9 & Darmayana & 17 & 11 & 18 & 31 & 77 \\
\hline 10 & Elza Erlinda S & 17 & 14 & 19 & 31 & 81 \\
\hline 11 & Eva Dhodo & 17 & 15 & 19 & 33 & 84 \\
\hline 12 & Giri Sandi P. & 12 & 16 & 18 & 36 & 82 \\
\hline 13 & Gita A. & 14 & 14 & 18 & 33 & 79 \\
\hline 14 & Indra P. & 11 & 11 & 12 & 33 & 67 \\
\hline 15 & Mira Sari A. & 12 & 14 & 19 & 34 & 79 \\
\hline 16 & Pelan Suaba & 11 & 17 & 18 & 31 & 77 \\
\hline 17 & Rezha F. & 10 & 12 & 18 & 35 & 75 \\
\hline 18 & Ricky Adi P. & 10 & 11 & 18 & 35 & 74 \\
\hline 19 & Ruditayasa & 11 & 12 & 15 & 31 & 69 \\
\hline 20 & Abdi W & 14 & 12 & 14 & 35 & 75 \\
\hline 21 & Abi W P & 10 & 16 & 18 & 34 & 78 \\
\hline 22 & Adi Sugiartawan & 12 & 14 & 18 & 34 & 78 \\
\hline 23 & Adi S. D & 12 & 14 & 19 & 27 & 72 \\
\hline 24 & Arimbawa Dewa & 12 & 15 & 19 & 36 & 82 \\
\hline 25 & Arya Dinata & 12 & 17 & 18 & 34 & 81 \\
\hline 26 & Budi Ariawan & 10 & 10 & 15 & 36 & 71 \\
\hline 27 & Eka Diana I Putu & 15 & 14 & 18 & 27 & 74 \\
\hline 28 & Juniarta & 11 & 12 & 18 & 31 & 72 \\
\hline 29 & Mediana I Kadek & 12 & 14 & 18 & 36 & 80 \\
\hline 30 & Nova Artana & 15 & 14 & 18 & 27 & 74 \\
\hline 31 & Pranata & 12 & 12 & 18 & 25 & 67 \\
\hline 32 & Raditya & 15 & 17 & 17 & 31 & 80 \\
\hline 33 & Sedana & 15 & 14 & 18 & 32 & 79 \\
\hline 34 & Tonny D & 11 & 11 & 18 & 32 & 72 \\
\hline 35 & Wahyu & 18 & 17 & 18 & 35 & 88 \\
\hline 36 & Riski A & 16 & 14 & 17 & 37 & 84 \\
\hline & Rerata & 12.89 & 13.67 & 17.19 & 32.39 & 76.14 \\
\hline
\end{tabular}

Keterangan : (1) Kefashian Berbahasa, (2) Kosakata, (3), Ketepatan Berbahasa (Tata Bahasa ),( 4) Metode Penyampaian Pesan

Nilai tertinggi mahasiswa berbicara sebagai seorang pramugraha dalam topik "taking guest order, dan situasi percakapan it is at 9 a.m. A guest asks some more coat hangers. Housekeeping order taker pick the telephone up and asks the roomboy to bring the guest order to the room."pada tabel diatas adalah 88 yang mampu diraih oleh 1 orang mahasiswa. Selanjutnya terdapat 11 orang meraih nilai A (80 -- 100). Selanjutnya nilai B ( 70 -- 79 ) diraih oleh 19 mahasiswa, sedangkan nilai C ( 57 -- 69 ) diraih oleh 6 orang mahasiswa. Sebanyak 5 orang mahasiswa meraih nilai 72 dan menjadi nilai yang paling sering muncul dari 36 orang mahasiswa.

Berdasarkan uraian nilai pada siklus I, diketahui bahwa mahasiswa yang mampu meraih nilai dengan kategori yang sangat baik atau $A=(80--100)$ sebanyak 11 orang 
( $30,55 \%$ ), mahasiswa yang meraih nilai dengan kategori baik atau $\mathrm{B}=(70--79)$ sebanyak 19 orang ( $52,77 \%)$, sedangkan kategori nilai cukup atau $\mathrm{C}=\left(\begin{array}{c}57--69) \\ \text { - }\end{array}\right.$ diraih oleh 6 orang ( $16,66 \%)$ dengan perincian mahasiswa dengan nilai 61 diraih oleh 1 orang, dan nilai 67 diraih oleh 2 orang, nilai 68 diraih oleh 1 orang, nilai 69 diraih oleh 1 orang. Berdasarkan uraian nilai tersebut terlihat peningkatan kemampuan berbicara, tetapi penerapan metode guided conversation pada siklus II tetap diterapkan untuk mendapatkan peningkatan yang lebih baik terutama dalam metode penyelesaian tugas dan kefasihan berbahasa sehingga kemampuan mahasiswa berbicara bahasa Inggris menjadi lebih baik, lancar, dan efektif. Secara terperinci, nilai mahasiswa berdasarkan empat aspek penilaian dapat dilihat pada tabel di bawah ini.

Nilai Mahasiswa Berdasarkan Empat Aspek Penilaian Siklus I

\begin{tabular}{|c|c|c|c|c|c|}
\hline $\begin{array}{l}\text { Nilai yang } \\
\text { diperoleh } \\
\text { Mahasiswa }\end{array}$ & $\begin{array}{c}\text { Kefasihan } \\
\text { Berbahas } \\
\text { a }\end{array}$ & $\begin{array}{c}\text { Kosakat } \\
\text { a }\end{array}$ & Tata Bahasa & $\begin{array}{l}\text { Nilai yang } \\
\text { diperoleh } \\
\text { Mahasiswa }\end{array}$ & $\begin{array}{c}\text { Metode } \\
\text { Penyelesain } \\
\text { Tugas }\end{array}$ \\
\hline & 1 & 2 & 3 & & 4 \\
\hline $\begin{array}{l}18-20 \\
\text { ( sangat } \\
\text { baik) }\end{array}$ & 1 & 0 & 26 & $\begin{array}{c}40-38 \\
\text { ( sangat } \\
\text { baik) }\end{array}$ & 0 \\
\hline $\begin{array}{l}15-17 \\
\text { (baik) }\end{array}$ & 10 & 10 & 6 & $\begin{array}{c}35-37 \\
\text { (baik) }\end{array}$ & 10 \\
\hline $\begin{array}{c}12-14 \\
\text { (cukup baik } \\
\text { ) }\end{array}$ & 12 & 19 & 4 & $\begin{array}{c}32-34 \\
\text { (cukup baik }\end{array}$ & 13 \\
\hline $\begin{array}{c}6-11 \\
\text { (kurang) }\end{array}$ & 13 & 7 & 0 & $\begin{array}{c}29-31 \\
\text { (kurang) }\end{array}$ & 8 \\
\hline $\begin{array}{c}1-5 \\
\text { (sangat } \\
\text { kurang ) }\end{array}$ & 0 & $\mathrm{O}$ & 0 & $\begin{array}{c}25-27 \\
\text { (sangat } \\
\text { kurang ) }\end{array}$ & 5 \\
\hline
\end{tabular}
adalah

Adapun rerata yang diperoleh pada pelaksanaan siklus I seterah penerapan

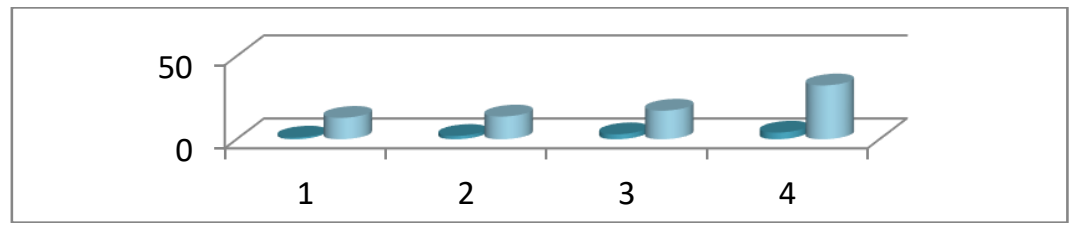

Dari grafik di atas, diketahui bahwa nilai rerata untuk kefasihan berbahasa adalah 12.89, nilai rerata untuk penggunaan kosa kata adalah 13.67, nilai rerata untuk ketepatan berbahasa adalah 17.19, dan nilai rerata untuk metode penyelesaian tugas adalah 32.39. Nilai rerata kelas yang diperoleh dari hasil perhitungan adalah 76,14.

Berdasarkan uraian di atas, dapat dikatakan bahwa kemampuan mahasiswa dalam berbicarasudah mulai meningkat dan nilai rerata kelas sudah termasuk dalam kategori B (70 -- 79). Namun pihak industri pariwisata membutuhkan lulusan dengan kemampuan berbahasa Inggris efektif yang lebih baik, yaitu tergolong pada kategori A ( 80 -- 100 ). Dari keempat aspek penilaian yang mendapatkan perhatian khusus pada siklus II adalah aspek kefasihan berbahasa, ketepatan penggunaan kosakata, dan metode penyelesaian tugas.

Hasil Siklus I Secara Kualitatif Analisis Tata Bahasa Inggris ( Ketepatan Berbahasa Inggris ) 
Jurnal Manajemen Pelayanan Hotel Akademi Komunitas Manajemen Perhotelan Indonesia (Anggreni \& Antara, halaman 45-73) Vol 3, No 1 Edisi Juni 2019

Analisis percakapan mahasiswa dari aspek ketepatan berbahasa Inggris dapat diuraikan sebagai berikut :

\section{Percakapan Mahasiswa}

\begin{tabular}{|l|l|}
\hline Pramugraha & \multicolumn{1}{|c|}{ Percakapan } \\
\hline Pramugaraha & $\begin{array}{l}\text { Good Morning, Housekeeping. Elza's speaking. What can I do for } \\
\text { you? }\end{array}$ \\
\hline Tamu & Good morning. Could I have some more coat hanger please ? \\
\hline Pramugraha & Sure. May I have your room number please! \\
\hline Tamu & Room 1110 \\
\hline Pramugraha & I beg your pardon Sir? \\
\hline Tamu & It is 1110 \\
\hline Pramugraha & And your name please Sir? \\
\hline Tamu & My name is Andrew \\
\hline Pramugraha & $\begin{array}{l}\text { So that some more coat hanger for room 1110, is that correct Mr. } \\
\text { Andrew ? }\end{array}$ \\
\hline Tamu & Yes, That's right \\
\hline Pramugraha & I'll send someone up right now \\
\hline Tamu & Oh Thank you \\
\hline Pramugraha & You are welcome Mr. Andrew. Have a nice day. Good bye. \\
\hline
\end{tabular}

Berdasarkan transkrip rekaman diatasdapat diuraikan tentang kemampuan penggunaan tata bahasa Inggris ( ketepatan berbahasa mahasiswa ) adalah tergolong dalam kategori sangat baik dengan skor 19. Penerapan ellipsis ( pelesapan ) pada kalimat : May I have your room number please ? Kemudian pada ujaran kedua : And yourname please ?Dalam susunan kedua kalimat ini terjadi pelesapan subjek ( I ) dan predikat I have ?. Penggunaan struktur kalimat sangat baik dan sesuai dengan kaedah tata bahasa Inggris seperti : Good Morning, Housekeeping. Elza's speaking. What can I do for you. ?. Pelesapan juga terjadi pada susunan kalimat Good Morning, Housekeeping. Pelesapan pada subjek dilakukan pada kalimat ini yang seharusnya : Good morning, It is housekeeping. Kemudian Elza's speaking dan what can I do for you? Penerapan struktur kalimat yang sesuai sudah terdapat pada kedua kalimat tersebut.

\section{Analisis Kefasihan Berbahasa Inggris Ketidaksesuaian penempatan} intonasi yang terjadi pada percakapan diatas adalah pada ujaran pramugaraha :/GOOD Morning, Housekeeping. Elza's speaking / dan ujaran IWHAT can I do for you ?Penempatan nada -fall rise terdapat pada kata -morning dan -elza. Berdasarkan pendekatan sikap dan emosi ( attitudinal approaches ), penempatan nada -fall rise tersebut menunjukkan sikap dan emosi yang ramah untuk mendapatkan informasi dari tamu yang datang menelepon ke housekeeping office.

Jika ditinjau dari pendekatan sikap dan emosi ( attitudinal approaches), penempatan nada -fall terdapat pada kata terakhir pada ujaran tersebut, yaitupada kata please pada ujaran May I have your room number please !

Pandangan pramugraha sudah diarahkan kepada lawan bicara. Hal ini disebabkan oleh pramugraha memiliki kemampuan menguasai makna kata-kata dalam percakapan dan menguasai topik percakapan. Pramugraha terlihat tenang, pandangan terarah, dan bersikap relaks. Akan tetapi, pramugraha masih menunjukkan mimik muka yang belum tepat, yaitu pada saat mengucapkan bahasa ekspresi greeting dan offering a help, seharusnya pramugraha memiliki mimik yang ramah dan tersenyum kepada lawan bicara. Keefektifan berbicara masih perlu ditingkatkan hal ini terlihat dari sikap pramugraha masih terlihat malu-malu dan grogi. 
Jurnal Manajemen Pelayanan Hotel Akademi Komunitas Manajemen Perhotelan Indonesia (Anggreni \& Antara, halaman 45-73) Vol 3, No 1 Edisi Juni 2019

\section{Analisis Penggunaan Kosa Kata bahasa Inggris}

Berdasarkan transkrip rekaman diatas dapat disimpulkan bahwamasih terdapat satu kesalahan penggunaan kosakata. Hal tersebut dapat diuraikan pada ujaran pramugraha : I'll send someone up right now. Sesuai dengan SOP Pramugraha dalam memberikan pelayanan kepada tamu melalui telepon bahwa ujaran yang harus disampaikan oleh pramugraha adalah certainly sir. I'll send someone up right now.

\section{Analisis Metode Penyelesain Tugas}

Kesalahan metode penyelesaian tugas yang terjadi pada percakapan di atas adalah :

\section{Aspek Isi Percakapan}

Pada kalimat-kalimat yang diujarkan oleh pramugraha pada percakapan di atas ditemukan kesesuaian pada pemarkah kohesi yang digunakan, yaitu dalam penggunaan bahasa ekspresi greeting, offering a help, introducing herself, asking the guest order, asking the guest name and the guest room number, repeating the guest order, thanking to the guest and vclosing conversation.

Kedua partisipan dalam percakapan tersebut saling memahami. Tamu memberikan respons kepada salam yang diujarkan pramugraha dengan menjawab ingn mendapatkan beberapa gantungan jas dan ingin dibawakan ke kamar. Dalam aturan gramatikal ditemukan relasi antara ujaran pramugraha dan tamu. Ketika dihubungkan dengan konteks di luar teks, yaitu pada saat tamumenelepon ke housekeeping office danpramugraha dapat memahami bahwa tamu sangat membutuhkan pelayanan pramugrahauntuk membawakan pesanan ke kamar. Pada dasarnya kedua partisipan tersebut dapat saling memahami karena adanya pengetahuan bersama tentang pelayanan pramugrha pada sebuah restoran. Semua kalimat-kalimat yang diujarkan pada percakapan di atas merupakan kalimat yang koheren, kohesi dan mendukung aspek isi percakapan tersebut.

\section{Aspek Formal Percakapan}

Berdasarkan topik dan situasi yang ditentukan ditemukan kesesuaian pada aspek formal percakapan, yaitu topikdan situasi sudah dikelola dengan baik dan lengkap. Artinya, terlihat percakapan dibangun dari bahasa ekspresi yang mengacu kepada menyapa tamu (greeting) sampai menyatakan siap untuk membawakan tamu pesanan dan menutup percakapan dengan mengucapkan terimakasih kepada tamu sehingga percakapan tersebut sudah memenuhi aspek formal percakapan yang utuh dan terpadu.

\section{Kemampuan Berbicara Mahasiswa pada Siklus II}

Penyampaian materi menggunakan metode guided conversation pada pembelajaran bahasa Inggris yang diterapkan pada mahasiswa MAP STIPAR Triatma Jaya menunjukkan bahwa penerapan metode guided conversation adalah efektif. Hal ini dibuktikan dengan peningkatan nilai yang dihasilkan mahasiswa pada siklus I. Hal yang sama juga terjadi pada siklus II. Hasil rekaman percakapan mahasiswa mengalami peningkatan, baik dalam kefasihan berbicara, ketepatan berbahasa, penerapan tata bahasa, namun metode penyelesaian tugas. Aspek penilaian yang lebih jelas terlihat peningkatannya adalah pada aspek metode penyelesaian tugas.

Hasil Belajar Mahasiswa Siklus II

\begin{tabular}{|l|l|c|c|c|c|c|}
\hline NO & NAMA MAHASISWA & \multicolumn{1}{|c|}{ NILAI } & \multicolumn{2}{|c|}{ SKOR } \\
\cline { 3 - 6 } & & 1 & 2 & 3 & 4 & \\
\hline 1. & Agnesia M. A & 10 & 11 & 15 & 32 & 68 \\
\hline 2. & Adi arta Y & 17 & 18 & 17 & 38 & 90 \\
\hline 3. & Andre K. A. & 11 & 12 & 16 & 32 & 71 \\
\hline 4 & Anik W. & 15 & 15 & 18 & 35 & 83 \\
\hline 5 & Ari Susila & 12 & 14 & 12 & 34 & 72 \\
\hline
\end{tabular}


Jurnal Manajemen Pelayanan Hotel Akademi Komunitas Manajemen Perhotelan Indonesia (Anggreni \& Antara, halaman 45-73) Vol 3, No 1 Edisi Juni 2019

\begin{tabular}{|l|l|r|r|r|r|l|}
\hline 6 & Ariska M. & 15 & 15 & 15 & 35 & 80 \\
\hline $\mathbb{N}$ & Aulia Nugraheni & 12 & 15 & 17 & 35 & 79 \\
\hline 8 & Bagus Restu A & 17 & 18 & 18 & 38 & 91 \\
\hline 9 & Darmayana & 17 & 17 & 18 & 37 & 89 \\
\hline 10 & Elza Erlinda S & 18 & 18 & 17 & 37 & 90 \\
\hline 11 & Eva Dhodo & 16 & 17 & 16 & 37 & 86 \\
\hline 12 & Giri Sandi P. & 12 & 14 & 16 & 34 & 76 \\
\hline 13 & Gita A. & 12 & 12 & 16 & 35 & 75 \\
\hline 14 & Indra P. & 12 & 14 & 15 & 35 & 76 \\
\hline 15 & Mira Sari A. & 15 & 17 & 17 & 35 & 84 \\
\hline 16 & Pelan Suaba & 14 & 17 & 18 & 37 & 86 \\
\hline 17 & Rezha F. & 15 & 17 & 15 & 35 & 82 \\
\hline 18 & Ricky Adi P. & 12 & 15 & 18 & 35 & 80 \\
\hline 19 & Ruditayasa & 12 & 15 & 16 & 37 & 80 \\
\hline 20 & Abdi W & 14 & 14 & 12 & 38 & 78 \\
\hline 21 & Abi W P & 12 & 15 & 15 & 35 & 77 \\
\hline 22 & Adi Sugiartawan & 12 & 17 & 12 & 35 & 76 \\
\hline 23 & Adi S. D & 14 & 15 & 18 & 38 & 85 \\
\hline 24 & Arimbawa Dewa & 17 & 17 & 16 & 37 & 87 \\
\hline 25 & Arya Dinata & 12 & 15 & 16 & 37 & 80 \\
\hline 26 & Budi Ariawan & 12 & 15 & 17 & 35 & 79 \\
\hline 27 & Eka Diana I Putu & 17 & 15 & 18 & 35 & 85 \\
\hline 28 & Juniarta & 10 & 12 & 16 & 35 & 73 \\
\hline 29 & Mediana I Kadek & 15 & 14 & 16 & 37 & 82 \\
\hline 30 & Nova Artana & 14 & 17 & 18 & 37 & 86 \\
\hline 31 & Pranata & 14 & 15 & 18 & 37 & 84 \\
\hline 32 & Raditya & 17 & 17 & 18 & 37 & 89 \\
\hline 33 & Sedana & 15 & 17 & 17 & 37 & 86 \\
\hline 34 & Tonny D & 17 & 15 & 17 & 37 & 86 \\
\hline 35 & Wahyu & 15 & 18 & 18 & 38 & 89 \\
\hline 36 & Riski A & 17 & 15 & 18 & 37 & 87 \\
\hline & Rerata & $\mathbf{1 4 . 1 1}$ & $\mathbf{1 5 . 3 9}$ & $\mathbf{1 6 . 3 9}$ & $\mathbf{3 5 . 9 7}$ & $\mathbf{8 1 . 8 6}$ \\
\hline & & & & \\
\hline
\end{tabular}

paling sering muncul, yaitu sebanyak 5 orang mahasiswa yang berhasil meraih nilai tersebut.

\section{Berdasarkan}

uraian nilai siklus II tersebut diketahui bahwa mahasiswa yang mampu meraih nilai dengan kategori yang sangat baik, atau $A=(80--100)$ sebanyak 24 orang ( $66,66 \%)$, mahasiswa yang meraih nilai dengan kategori baik, atau $B=(70$-79 ) sebanyak 11 orang (30,55\%), sedangkan kategori nilai cukup atau $\mathrm{C}=($ 57 - 69 ) diraih oleh 1 orang (2,77\%).

Nilai tertinggi mahasiswa berbicara sebagai seorang pramugraha dalam topik first act you are as order taker at housekeeping office. It is at 2 pm your guest calls you and ask you to come to the room because she has a problem of blue tub. The guest name is Ms. Lucia at room 202.

Kriteria percakapan adalah you act as roomboy and do as SOP of room boy to the guest at the room. You have to explain what you should do for the problem. Handle the guest complaint at the room pada tabel diatas adalah 91 yang mampu diraih oleh 1 orang mahasiswa. Selanjutnya terdapat 24 orang meraih nilai $A(80-100)$ dengan perincian nilai tertinggi 91 diraih oleh satu orang mahasiswa, nilai 90, 87, 85, 84, dan 82 masing- masing diraih oleh dua orang mahasiswa. Nilai 89 diraih oleh 3 orang , nilai 86 diraih oleh 5 orang, nilai 83 diraih oleh 1 orang mahasiswa, dan nilai 80 diraih oleh 4 orang. Selanjutnya nilai B ( 70 -- 79 ) diraih oleh 11 mahasiswa, sedangkan nilai $\mathrm{C}$ ( 57 -- 69 ) diraih oleh satu orang mahasiswa. Nilai 86 menjadi nilai yang
Uraian nilai tersebut menunjukkan telah terjadi peningkatan kemampuan berbicara dengan penerapan metode guided conversation pada siklus II.

Peningkatan terjadi pada ketiga aspek penilaian, yaitu aspek kefasihan berbahasa (14.11), aspek ketepatan berbicara (15.39), dan aspek metode penyelesaian tugas ( 35.97), tetapi penurunan terjadi pada aspek tata bahasa (16.39). Kesalahan penggunaan tata bahasa tersebut disebabkan oleh pengembangan topic dan situasi percakapan yang semakin lengkap yaitu dari tamu menelepon ke housekeeping office kemudian pramugraha datang ke kamar tamu dan menangani kelehun tamu sampai masalah terselesaikan. Namun secara keseluruhan kemampuan berbicara efektif mahasiswa semakin meningkat. Secara terperinci, nilai mahasiswa berdasarkan empat aspek penilaian dapat dilihat pada tabel di bawah ini. 


\begin{tabular}{|c|c|c|c|c|c|}
\hline \multicolumn{6}{|c|}{ Nilai Mahasiswa Berdasarkan Empat Aspek Penilaian Siklus II } \\
\hline $\begin{array}{l}\text { Nilai yang } \\
\text { diperoleh } \\
\text { mahasiswa }\end{array}$ & $\begin{array}{c}\text { Kefasiha } \\
n \\
\text { Berbahas } \\
a\end{array}$ & $\begin{array}{c}\text { Ketepata } \\
\text { n } \\
\text { Berbahas } \\
\text { a }\end{array}$ & $\begin{array}{c}\text { Tata } \\
\text { Bahas } \\
\text { a }\end{array}$ & $\begin{array}{c}\text { Nilai yang } \\
\text { diperoleh } \\
\text { mahasiswa }\end{array}$ & $\begin{array}{c}\text { Metode } \\
\text { Penyelesain } \\
\text { Tugas }\end{array}$ \\
\hline & 1 & 2 & 3 & & 4 \\
\hline $\begin{array}{c}18-20 \\
\text { ( sangat baik) }\end{array}$ & 1 & 4 & 12 & $\begin{array}{c}38-40 \\
\text { ( sangat baik) }\end{array}$ & 5 \\
\hline $\begin{array}{l}15-17 \\
\text { (baik) }\end{array}$ & 16 & 23 & 21 & $\begin{array}{l}35-37 \\
\text { (baik) }\end{array}$ & 27 \\
\hline $\begin{array}{c}12-14 \\
\text { (cukup baik) }\end{array}$ & 16 & 7 & 3 & $\begin{array}{c}32-34 \\
\text { (cukup baik ) }\end{array}$ & 4 \\
\hline $\begin{array}{c}6-11 \\
\text { (kurang) }\end{array}$ & 3 & 1 & 0 & $\begin{array}{l}29-31 \\
\text { (kurang) }\end{array}$ & 0 \\
\hline $\begin{array}{c}1-5 \\
\text { (sangat kurang }\end{array}$ & 0 & 0 & 0 & $\begin{array}{c}25-27 \\
\text { (sangat kurang ) }\end{array}$ & 0 \\
\hline
\end{tabular}

Nilai tertinggi dan terendah dari aspek penilaian 1 (kefasihan berbahasa) adalah 18 (1 orang mahasiswa) dan 10 ( 2 orang mahasiswa). Nilai tertinggi dan terendah aspek penilaian 2 (ketepatan berbahasa) adalah 18 ( 4 orang mahasiswa) dan 11 ( 1 orang mahasiswa). Nilai tertinggi dan terendah aspek penilaian 3 (tata bahasa) adalah 18 ( 12 orang mahasiswa) dan 12 (3 orang mahasiswa). Nilai tertinggi dan terendah aspek penilaian 4 (metode penyelesaian tugas ) adalah 38 (5 orang mahasiswa) dan 32 (2 orang mahasiswa).

\section{Nilai Rerata Empat Aspek Penilaian Siklus II}

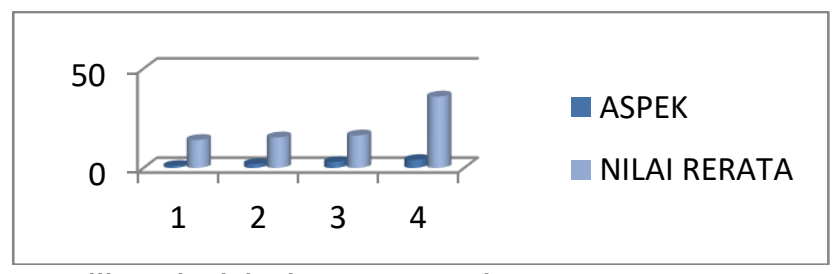

Dari grafik di atas, diketahui bahwa nilai rerata untuk kefasihan berbahasa adalah 14.11, nilai rerata untuk aspek penggunaan kosa kata adalah 15.39 , nilai rerata untuk aspek ketepatan berbahasa adalah 16.39, dan nilai rerata untuk aspe metode penyelesaian tugas adalah 35.97. Nilai rerata kelas yang diperoleh dari hasil perhitungan adalah 81.86. Berdasarkan uraian di atas, dapat dikatakan bahwa kemampuan mahasiswa dalam berbicarasudah mulai meningkat dan termasuk dalam kategori A (80 -- 100).

Hasil Siklus II Secara Kualitatif Analisis Tata Bahasa Inggris ( Ketepatan Berbahasa Inggris )

Berikut diuraikan kesalahan tata bahasa Inggris mahasiswa pada percakapan dibawah ini yaitu : 
Jurnal Manajemen Pelayanan Hotel Akademi Komunitas Manajemen Perhotelan Indonesia (Anggreni \& Antara, halaman 45-73) Vol 3, No 1 Edisi Juni 2019

\section{Percakapan 1}

\begin{tabular}{|l|l|}
\hline Pramugraha & \multicolumn{1}{|c|}{ Percakapan } \\
\hline Pramugaraha & $\begin{array}{l}\text { Good afternoon housekeeping. Elza's speaking. What can I do for } \\
\text { you? }\end{array}$ \\
\hline Tamu & $\begin{array}{l}\text { Goodafternoon. I have something problem in my room. Could you } \\
\text { come to my room please? }\end{array}$ \\
\hline Pramugraha & Sure. May I know your problem ? \\
\hline Tamu & I am not sure. The problem is at the bathroom \\
\hline Pramugraha & Alright. May I know your name and your room number please? \\
\hline Tamu & My name is Luzia. My room number is 202 \\
\hline Pramugraha & $\begin{array}{l}\text { Thank you Ms. Luzia. So you need someone to come to your room } \\
\text { for handling problem in the bathroom. Is that correct? }\end{array}$ \\
\hline Tamu & Yes It is. Please come as soon as possible. \\
\hline Pramugraha & Yes .Of course madm. I'll send someone at once. Please wait \\
\hline Tamu & Thank you very much. Good bye \\
\hline Pramugraha & Your welcome. Good bye \\
\hline & At The Room \\
\hline Pramugraha & $\begin{array}{l}\text { Good afternoon madam. My name is Indra. I come to help you. } \\
\text { Could you show me what the problem is ? }\end{array}$ \\
\hline Tamu & Oh just come and follow me please \\
\hline Pramugraha & $\begin{array}{l}\text { So you has problem with your blue tub. I'm so sorry about this } \\
\text { problem madam. Now, I am show you how to use it. Look at this } \\
\text { madam I show you the instruction! }\end{array}$ \\
\hline Tamu & Oooo thank you very much for your help \\
\hline Pramugraha & I'm so glad to help you madam. Anything else madam ? \\
\hline Tamu & No, everythings right now. Thank you \\
\hline Pramugraha & Your welcome madam. Have a nice staying here. Good bye \\
\hline
\end{tabular}


Berdasarkan transkrip rekaman dapat diuraikan tentang kemampuan penggunaan tata bahasa Inggris ( ketepatan berbahasa mahasiswa ) adalah tergolong dalam kategori sangat baik dengan skor 19. Penerapan ellipsis ( pelesapan ) pada kalimat : May I have your room number please ? Kemudian pada ujaran kedua : And yourname please ? Dalam susunan kedua kalimat ini terjadi pelesapan subjek (I) dan predikat I have ?. Penggunaan struktur kalimat sangat baik dan sesuai dengan kaedah tata bahasa Inggris seperti : Good Morning, Housekeeping. Elza's speaking. What can I do for you. ?. Pelesapan juga terjadi pada susunan kalimat Good Morning, Housekeeping. Pelesapan pada subjek dilakukan pada kalimat ini yang seharusnya : Good morning, It is housekeeping. Kemudian Elza's speaking dan what can I do for you ?. Penerapan struktur kalimat yang sesuai sudah terdapat pada kedua kalimat tersebut.

Sedangkan kesalahan dalam susunan sruktur kalimat ditemukan pada ujaran pramugraha Indra : So you has problem with your blue tub. I'm so sorry about this problem madam. Now, I am show you how to use it. Look at this madam I show you the instruction! Pada kalimat ini seharusnya pramusaji mengujarkan kalimat, pramugraha ( Indra ) : So you have a problem with your blue tub. I'm so sorry about this problem madam. Then, I show you how to use it. Look at this madam I show you the instruction! Perbaikan penggunaan verb has dengan verb have disebabkan oleh kesesuaian dengan subjeck I yang harus diikuti oleh verb have. Susunan kalimat ini merupakan kalimat yang merujuk pada tenses simple present tense.

\section{Analisis Kefasihan Berbahasa Inggris}

Ketidaksesuaian penempatan intonasi yang terjadi pada percakapan diatas adalah pada ujaran pramugaraha :SURE. May I know your problem ?. Penempatan nada fall ( ) pada kata sure mengindikasikan sikap dan emosi ( attitudinal approaches ) yang ramah dan siap membantu tamu dalam menanggani keluhan yang dialami di kamar. Ketidaksesuain penempatan intonasi juga terjadi pada ujaran : GOOD afternoon madam. My name is Indra. I come to help you. Could you show me what the problem is ?Penempatan nada -fall rise terdapat pada kata -good. Hal ini berdasarkan pendekatan sikap dan emosi ( attitudinal approaches ), penempatan nada -fall rise tersebut menunjukkan sikap dan emosi yang ramah untuk mendapatkan informasi dari tamu pada saat di kamar.

Pandangan pramugraha sudah diarahkan kepada lawan bicara. Hal ini disebabkan oleh pramugraha memiliki kemampuan menguasai makna kata-kata dalam percakapan dan menguasai topik percakapan. Pramugraha terlihat tenang, pandangan terarah, dan bersikap relaks. Pramugraha juga menunjukkan mimik muka yang sangat tepat, yaitu mimik yang sangat ramah dan tersenyum pada saat mengucapkan bahasa ekspresi greeting dan offering a help. Keefektifan berbicara sudah tercipta pada percakapan ini, hal tersebut terlihat dari sikap pramugraha masih terlihat malu-malu dan grogi.

\section{Analisis Penggunaan Kosa Kata bahasa Inggris}

Berdasarkan transkrip rekaman diatas dapat disimpulkan bahwa masih terdapat satu kesalahan penggunaan kosakata. Hal tersebut dapat diuraikan pada ujaran pramugraha :Yes .Of course madm. l'll send someone at once. Please wait. Penggunaan kata yes dan of course dalam ujaran pramugraha diatas tidak sesuai karena memiliki makna yang sama sehingga seharusnya pramugraha hanya mengujarkan yes atau of couse

\section{Analisis Metode Penyelesain Tugas}

Kesalahan metode penyelesaian tugas yang terjadi pada percakapan di atas adalah :

\section{Aspek Isi Percakapan}

Pada kalimat-kalimat yang diujarkan oleh pramugraha pada percakapan di atas ditemukan kesesuaian pada pemarkah kohesi yang digunakan, yaitu dalam penggunaan bahasa ekspresi greeting, offering a help, introducing herself, asking the guest order, asking the guest name and the guest room number, repeating the guest order, handling complaint, giving 
instruction, thanking to the guest and closing conversation.

Kedua partisipan dalam percakapan tersebut saling memahami. Tamu memberikan respons kepada salam yang diujarkan pramugraha dengan menjawab ingn mendapatkan beberapa gantungan jas dan ingin dibawakan ke kamar. Dalam aturan gramatikal ditemukan relasi antara ujaran pramugraha dan tamu. Ketika dihubungkan dengan konteks di luar teks, yaitu pada saat tamumenelepon ke housekeeping office dan pramugraha dapat memahami bahwa tamu sangat membutuhkan pelayanan pramugraha untuk membantu menyelesaikan masalah tamu di kamar. Pada dasarnya kedua partisipan tersebut dapat saling memahami karena adanya pengetahuan bersama tentang pelayanan pramugraha pada sebuah hotel. Semua kalimatkalimat yang diujarkan pada percakapan di atas merupakan kalimat yang koheren, kohesi dan mendukung aspek isi percakapan tersebut.

\section{Aspek Formal Percakapan}

Berdasarkan topik dan situasi yang ditentukan ditemukan kesesuaian pada aspek formal percakapan, yaitu topikdan situasi sudah dikelola dengan baik dan lengkap. Artinya, terlihat percakapan dibangun dari bahasa ekspresi yang mengacu kepada menyapa tamu ( greeting) sampai menyatakan siap untuk membawakan tamu pesanan dan menutup percakapan dengan mengucapkan terimakasih kepada tamu sehingga percakapan tersebut sudah memenuhi aspek formal percakapan yang utuh dan terpadu.

\section{Mekanisme penerapan metode guided conversation tersebut pada mahasiswa MAP STIPAR Triatma Jaya}

Penelitian tindakan kelas pada mahasiswa MAP Diploma III di STIPAR Triatma Jaya pada pembelajaran berbicara talks as interaction dalam berperanan sebagai pramugraha dengan topic topik making up the guest room dengan situasi yang ditentukan, yaitu it is at 08.00 a.m., one couple in room 202 call to housekeeping office. They ask roomboy to make up their room at the time and they have a complaint about the bath tub in the bath room. Tes awal ini dimaksudkan untuk mengetahui kondisi mahasiswa sebenarnya tentang kemampuan berbicara mahasiswa dalam bahasa Inggris. Setelah diketahui gambaran awal, dilakukan persiapan penelitian, yaitu menyusun rencana pengajaran sekaligus menyusun bahan pembelajaran melalui tahap-tahapan guided conversation dan membuat instrumen penelitian. receiving the guest in the restaurantmenggunakan metode guided conversationdilaksanakan dalam dua siklus, yaitusiklus I (6 Juni 2018 - 8 Juni 2014 ), 11 Juni 2018 dan siklus II ( 20 Juni 2018-22 Juni 2018 ), tes siklus II pada tanggal 25 Juni 2018.

\section{Siklus I}

Siklus I terdiri atas perencanaan, pelaksanaan, observasi, dan refleksi. Seluruh kegiatan pada siklus I ini dijabarkan sebagai berikut :

1. Perencanaan siklus I disusun untuk merencanakan beberapa persiapan yang berhubungan dengan pelaksanaan tindakan penerpan metode guided conversation.

2. Memilih materi

Dalam proses memilih materi pada siklus I disiapkan materi dan contoh percakapan-percakapan sesuai dengan topik, tetapi dengan situasi yang sedikit berbeda. Materi yang diajarkan pada siklus I adalah materi greeting, introducing oneself, offering a help, time, number, spelling, request dan housekeeping facilities ( room facilities, room supplies, room amenities ). Semua materi disajikan dalam 3 kali pertemuan, yaitu satu kali pertemuan di sampaikan dalam empat jam perkuliahan ( 200 menit )

3. Menyiapkan instrumen penelitian

Dalam perencanaan ini dilakukan persiapan instrumen penelitian yaitu menyiapkan field note, laptop, LCD projector, camera dan handycam,kuesioner, skala penilaian ( rubrik)

4. Pelaksanaan Siklus I

Pembelajaran berbicara bahasa Inggris talks as interaction pada Siklus I ini terdiri atas tiga kali pertemuan, yaitu pertemuan I pada 6 Juni 2018, pertemuan 
II pada 7 Juni 2018 dan pertemuan III pada 8 Juni 2018. Penerapan metode guided conversation sudah dilakukan pada siklus ini. Pada pertemuan keempat dilaksanakan tes siklus I, yaitu Senin, 11 Juni 2018, sebagai tahapan evaluasi untuk mengetahui peningkatan kemampuan berbicaratalks as interaction mahasiswa jika dibandingkan dengan tes pratindakan. Hasil tes berbicara mahasiswa disimpan dalam rekaman untuk mendapatkan hasil evaluasi yang lebih valid. Evaluasi dilakukan dengan menggunakan rubrik penilian berbicara.

\section{Hasil Jurnal Kegiatan Siklus I}

Pada pertemuan pertama, yaitu Rabu, 6 Juni 2018 ketika dosen memasuki ruangan kelas, mahasiswa mengucapkan salam (greeting), "good morning madam, how are you today" dan direspons oleh dosen dengan salam ( greeting ), "good morning, I 'm well. And you dear ?" Selain itu dosen mengecek kehadiran mahasiswa. Pada saat itu mahasiswa hadir $100 \%$ mahasiswa. Pada pertemuan pertama disajikan materi greeting, offering a help, time, number, spelling.

Dalam melatih mahasiswa untuk menguasai materi tersebut pada awalnya dijelaskan penggunaan bahasa ekspresi greeting dan salutation yang tepat sesuai dengan situasi yang ditentukan, misalnya seorang tamu wanita menelepon ke housekeeping office pada pukul 10 a.m.Pada latihan berbicara ini digunakan bahan ajar yang telah disiapkan oleh peneliti. Melatih mahasiswa dalam menggunakan bahasa ekspresi pada saat menerima telepon dari tamu dari menggunakan salam yang tepat sesuai dengan jam tamu menelepon, memperkenalkan diri, menyebutkan section, menawarkan bantuan dengan ekprsi yang tepat dan santun, seperti : Good morning housekeeping, Rika is speaking. What can I do for you please?. Kalimat ini terkesan sederhana namun harus dilatih secara rutin untuk mendapatkan hasil berbicara mahasiswa yang tepat dan santun dalam pengucapan ( pronounciation), tekanan (stress) dan nada yang tepat sehingga menghasilkan kemampuan berbicara yang efektif dan native like. Kegiatan berbicara ini dilakukan dalam pair atau berpasangan secara bergantian untuk mendapatkan kemampuan berbicara yang diinginkan dalam dunia perhotelan.

Juni 2018, adalah pertemuan kedua diberikan materi tentang bahasa-bahasa ekspresi yang merujuk kepada introducing oneself, spelling, making and asking request ( guest order ). Awal pertemuan diberikan cara efektif untuk memperkenalkan diri ( introducing oneself) pada saat pramugraha memasuki guest room dan menelepon ke kamar tamu ( guest room ). Penggunaan bahasa ekpresi kesantunan dan nada yang tepat dalam memperkenalkan diri kepada tamu dipraktikan dalam bentuk percakapan, contoh : housekeeping : good morning Mr. Steven, My name's Rika, your roomaid for today. If you need my service, please dial number 003, it is the direction number of housekeeping office. I will come to you and help you, sir. Guest: Thank you Rika. Please come to My room, I have problem with my blue tube. Housekeeping : certainly, with my please Mr. Steven, I will come in a minute. Percakapan tersebut dilatih berkali-kali untuk mendapatkan kemampuan berbicara mahasiswa yang efektif dan native like. Praktik ini dilakukan di ruang praktik housekeeping untuk menambah suasana yang membuat mahasiswa lebih menjiwai peran sebagai pramugraha.

Pada hari ketiga, siklus I, yaitu Jumat, 8Juni 2018 materi yang disajikan adalah request dan housekeeping facilities ( room facilities, room supplies, room amenities ). Penyampaian materi taking request, room facilities, room supplies, dan room amenities dilakukan pada 50 menit pertama. Kemudian membuat kuis tentang room facilities, room supplies, room amenities dilakukan dengan tujuan agar mahasiswa dapat membedakan room facilities, rom supplies dan room amenities. Pemahaman dan penguatan dilakukan juga dengan bermain peran dengan situasi " $\mathrm{Mr}$ and Mrs. Barnet ask bedroom supplies (tissue paper ), at 10 a.m. Dalam percakapan ini harus dimulai oleh pemberiaan salam ( greeting ), offering a help, taking order( request), saying thank you and closing 
conversation. Suasana kelas menjadi menarik dan mahasiswa dilibatkan dalam pembelajaran dan materi lebih cepat dikuasai.

\section{Hasil Jurnal Kegiatan Siklus I Tes Akhir}

Pada Jumat, 8Juni 2018 diadakan tes akhir siklus I. Mahasiswa diminta duduk dalam kelompoknya masingmasing. Jumah mahasiswa sebanyak 36 orang. Setiap kelompok terdiri dari 2 mahasiswa, sehingga terdapat 13 kelompok. Satu mahasiswa berperan sebagai tamu dan satu mahasiswa berperan sebagai pramugraha. Dosen memberikan topik percakapan,taking guest order, dan situasi percakapan it is at 9 a.m. A guest asks some more coat hangers. Housekeeping order taker pick the telephone up and asks the roomboy to bring the guest order to the room.

Sebelum mahasiswa memerankan perannya masing-masing, diberikan kesempatan selama 15 menit untuk menyiapkan percakapan pada masingmasing group. Pengundian nomor group dilakukan untuk menentukan giliran mempraktikan percakapan tersebut. Setiap penyaji diberikan kesempatan 15 menit untuk bermain peran, sehingga dibutuhkan 195 menit ( 4 jam perkuliahan). Kelompok yang belum mendapatkan giliran disilakan untuk menunggu di luar kelas sehingga suasana kelas menjadi tenang dan hasil rekaman menjadi jelas.

\section{Observasi dan Refleksi Siklus I}

Hal yang dapat disimpulkan dari observasi yang dilakukan pada tes akhir siklus I adalah kemampuan mahasiswa dalam menggunakan kosa kata dan ekpresi bahasa mulai meningkat dan sesuai dengan situasi yang ditentukan. Aspek metode menyelesaikan tugas masih perlu ditingkatkan. Aspek ketepatan berbahasa sudah meningkat. Kepasihan berbicara perlu ditingkatkan, mahasiswa terlihat ragu-ragu dalam mengujarkan kalimat-kalimat yang digunakan, mimik wajah, dan sikap mahasiswa sudah mulai tenang dan terarah pandangan matanya kepada lawan berbicara. Kemampuan berbicara mahasiswa masih kurang dalam berbicara dengan mimik wajah, dan sikap yang luwes menjadi perhatian khusus pada siklus II.Pada siklus I diketahui bahwa nilai rerata untuk kefasihan berbahasa adalah 12.89, nilai rerata untuk penggunaan kosa kata adalah 13.67, nilai rerata untuk ketepatan berbahasa adalah 17.19, dan nilai rerata untuk metode penyelesaian tugas adalah 32.39. Nilai rerata kelas yang diperoleh dari hasil perhitungan adalah 76,14. Berdasarkan uraian di atas, mengindikasikan bahwa kemampuan mahasiswa dalam berbicarasudah mulai meningkat dan nilai rerata kelas sudah termasuk dalam kategori B (70 -- 79). Namun pihak industri pariwisata membutuhkan lulusan dengan kemampuan berbahasa Inggris efektif yang lebih baik, yaitu tergolong pada kategori A ( 80 -- 100 ).

\section{Siklus II}

Siklus II terdiri atas perencanaan, pelaksanaan, observasi, dan refleksi. Seluruh kegiatan pada siklus II adalah sama dengan pelaksnaan siklus I yaitu :

\section{Perencanaan}

Perencanaan siklus II terdiri dari : (1) skenario pembelajaran dibuat untuk digunakan pada siklus II dan mempersiapkan alat dan bahan mengajar

(2) mempersiapkan materi ajar;(3) mempersiapkan test akhir siklus II; dan (4) mempersiapkan instrumen penelitian

\section{Skenario Pembelajaran}

Skenario pembelajaran dalam siklus II terdiri atas tiga kali pertemuan yaitu pertemuan pertama pada Jumat, 4 April 2014. Pertemuan kedua, yaitu siklus II ( 20 Juni 2018 - 22 Juni 2018 ), tes siklus II pada tanggal 25 Juni 2018.

\section{Materi Ajar}

Pada siklus II diberikan materi yang menunjang topic dan situasi percakapan yang digunakan dalam bermain peran. Materi tersebut adalah asking the guest name and room number, giving direction, handling complain, repeating the guest's order. Lam 3 kali pertemuan dimana satu kali pertemuan disajikan dlam 200 meni ( 4 jam perkulihan ). Semua materi ini disampaikan topik percakapan pada tes akhir siklus II adalah first act you are as order taker at housekeeping office. It is at 
2 pm your guest calls you and ask you to come to the room because she has a problem of blue tub. The guest name is Ms. Lucia at room 202. Kriteria percakapan adalah you act as roomboy and do as SOP of room boy to the guest at the room. You have to exlain what you should do for the problem. Handle the guest complaint at the room.

\section{Instrumen Penelitian}

Dalam perencanaan ini dilakukan persiapan instrumen penelitian, yaitu menyiapkan field note, laptop, LCD projector, camera dan handycam,pedoman

wawancara,kuesioner, skala penilaian.

\section{Pelaksanaan Siklus II}

Siklus ini terdiri atas tiga kali pertemuan, yaitu siklus II ( 20 Juni 2018 22 Juni 2018 ), tes siklus II pada tanggal 25 Juni 2018. Pembelajaran diberikan dengan menerapkan metode guided conversation. Tes akhir siklus II dilaksanakan untuk mengetahui peningkatan kemampuan berbicara talk as interactionmahasiswa jika dibandingkan dengan tes siklus I. Semua kegiatan yang dilaksanakan pada siklus II direkam dalam rekaman dan jurnal kegiatan.

\section{Hasil Jurnal Siklus II Pertemuan I}

Pada pertemuan pertama, yaitu Rabu, 20 Juni 2018. Pada pertemuan pertama diberikan materi tentang memberikan asking the guest name and room number dan giving direction. Pemberian materi ini dimaksudkan untuk mendukung pengetahuan mereka dalam menangani keluhan tamu dan sesuai dengan topic dan situasi percakapan pada tes siklus II. Setelah penyajian materi mahasiswa diberikan kesempatan pada 100 menit terakhir untuk bermain peran dengan topic giving direction.

\section{Hasil Jurnal Siklus II Pertemuan II}

Pada hari kedua, siklus II, Kamis, 21 Juni 2018, diberikan beberapa pertanyaan dalam sebuah pedoman wawancara, yang sangat terkait dengan urutan -urutan kerja sesuai dengan SOP seorang pramugraha dan mendukung materi giving direction dan handling complain.Adapun pedoman wawancara tersebut adalah (1) could you introduce your self please ?; (2) how do you greet your guest if you want to come to the guest room ?(3) how do you greet your guest if you pick the telephone up (4) What is room supplies ? (5) What is room facilities? (6) what is room amenities (7) how can you handle complaint? (8) what is your expression if you ask the guest name, the guest order, the guest room number?.

Semua pertanyaan yang terangkum dalam pedoman wawancara tersebut terkait dengan materi pembelajaran yang telah disajikan pada pertemuan-pertemuan sebelumnya. Hal ini juga sebagai penguatan terhadap penguasaan materi-materi yang telah disajikan sehingga mahasiswa benarbenar memahami dan menguasai bahasa Inggris yang digunakan pramugraha pada sebuah hotel. Dalam kegiatan ini sangat jelas terlihat antusiasme mahasiswa untuk menyiapkan diri untuk mendapatkan hasil interview yang terbaik. Pedoman wawancara ini hampir sama dengan pedoman wawancara yang dikuti pada saat menyiapkan diri dalam seleksi on the job training. Selanjutnya, kegiatan interview mahasiswa dilaksanakan sampai semua mahasiswa mendapatkan giliran. Penyaji pertama dipersilakan untuk memasuki ruang kelas untuk mengikuti interview, sedangkan yang lain menunggu di luar kelas untuk menghindari adanya kesamaan jawaban dari tiap-tiap mahasiswa. Kegiatan ini dilakukan selama tiga jam penyajian, yaitu 150 menit. Semua kegiatan ini direkam dalam sebuah video dan hasil rekaman ini dibagikan kepada mahasiswa sehingga bisa melihat langsung kemampuan mereka masing-masing.

\section{Hasil Jurnal Siklus II Pertemuan III}

Pada hari ini, yaitu Jumat, 22 Juni 2014 diadakan pertemuan ketiga pada siklus II. Pada pertemuan ini diberikan persiapan tes akhir siklusll. Setiap mahasiswa harus menyiapkan percakapannya masing-masing meskipun setiap mahasiswa berada dalam sebuah grup yang beranggotakan 2 orang, satu orang berperan sebagai pramugraha dan satu orang berperan sebagai tamu. Topik dan situasi percakapan ditentukan. Topik 
percakapan adalah first act you are as order taker at housekeeping office. It is at 2 pm your guest calls you and ask you to come to the room because she has a problem of blue tub. The guest name is Ms. Lucia at room 202. Kriteria percakapan adalah you act as roomboy and do as SOP of room boy to the guest at the room. You have to explain what you should do for the problem. Handle the guest complaint at the room.

Mahasiswa diberikan kesempatan untuk menyiapkan percakapan pada grup masing-masing selama lima belas menit kemudian nomor grup diundi untuk menentukan grup yang menjadi penyaji pertama dan seterusnya. Penyaji pertama dipersilakan untuk memasuki ruang kelas dan mempraktikkan percakapan masingmasing, sedangkan grup yang lain menunggu di luar kelas.

\section{Hasil Jurnal Siklus I Tes Akhir}

Pada Jumat, 22 Juni 2018 diadakan tes akhir siklus II. Mahasiswa diminta duduk dalam kelompoknya masing-masing. Jumah mahasiswa sebanyak 36 orang. Setiap kelompok terdiri dari 2 mahasiswa, sehingga terdapat 13 kelompok. Satu mahasiswa berperan sebagai tamu dan satu mahasiswa berperan sebagai pramugraha. Dosen memberikan topik percakapan, first act you are as order taker at housekeeping office. It is at $2 \mathrm{pm}$ your guest calls you and ask you to come to the room because she has a problem of blue tub. The guest name is Ms. Lucia at room 202. Kriteria percakapan adalah you act as roomboy and do as SOP of room boy to the guest at the room. You have to explain what you should do for the problem. Handle the guest complaint at the room.

\section{Observasi dan Refleksi Siklus II}

Berdasarkan observasi yang dilakukan pada saat tes akhir siklus II dapat disimpulkan beberapa hal, yaitu minat dan kemampuan mahasiswa berbicara bahasa Inggris mulai mengalami peningkatan jika dibandingkan dengan hasil tes pratindakan dan tes akhir siklus I. Hal ini terlihat dari keempat aspek penilaian yaitu terutama pada aspek metode penyampiaan pesan dan aspek kefasihan berbahasa. Mahasiswa sudah mulai menggunakan bahasa-bahasa ekspresi yang lebih tepat sesuai dengan urutan-urutan yang ditentukan dalam SOP pramugraha. Pada siklus II, nilai rerata untuk kefasihan berbahasa adalah 14.11, nilai rerata untuk aspek penggunaan kosa kata adalah 15.39, nilai rerata untuk aspek ketepatan berbahasa adalah 16.39, dan nilai rerata untuk aspe metode penyelesaian tugas adalah 35.97. Nilai rerata kelas yang diperoleh dari hasil perhitungan adalah 81.86. Berdasarkan uraian di atas, dapat dikatakan bahwa kemampuan mahasiswa dalam berbicara sudah mulai meningkat dan termasuk dalam kategori A (80 -- 100) .

\section{Simpulan}

Berdasarkan hasil penelitian yang telah diuraikan, simpulan hasil penelitian yang dapat diuraikan pada bab ini adalah :

1. Kemampuan mahasiswa dalam berbicara talks as interaction diuraikan sebagai berikut :

A. Sebelum menerapkan metode guided conversation pada pembelajaran talks as interaction disimpulkan bahwa :

1) Dari 36 mahasiswa hanya 13 mahasiswa berada pada skor 1517 ( baik ); 11 orang memiliki kemampuan cukup baik (12-14) ; 12 orang memiliki kemampuan kurang dalam aspek kefasian berbicara.

2) Sebanyak 9 orang memiliki kemampuan baik ( 15-17); 26 mahasiswa memiliki kemampuan cukup baik (12-14), dan 1 mahasiswa yang tergolong kurang keampuannya dalam ketepatan penggunaan kosa kata.

3) Sebanyak 2 mahsiswa yang memiliki kemampuan sangat baik; 29 orang tergolong berkemampuan baik, 4 orang tergolong berkemampuan cukup baik dan hanya 1 orang yang memiliki kemampuan kurang dalam ketepatan berbahasa.

4) Sebanyak 3 orang mahasiswa yang tergolong berkemampuan cukup, 27 orang tergolong berkemampuan kurang dan 6 orang termasuk berkemampuan 
sangat kurang dalam aspek penyelesaian tugas.

B. Kemampuan mahasiswa dalam berbicara talk as interaction, setelah menggunakan metode guided conversationdapat dibagi menjadi dua siklus, yaitu seperti di bawah ini.

1) Pada siklus I, metode guided conversation diterapkan, mahasiswa yang mampu meraih nilai dengan kategori yang sangat baik, $A=(80-100)$ sebanyak 11 orang ( $30,55 \%), 19$ orang ( $52,77 \%$ ) pada kategori baik, 6 orang $(16,66 \%)$ pada kategori cukup $\mathrm{C}=($ 57-69) Berdasarkan uraian nilai tersebut sudah terlihat peningkatan kemampuan berbicara namun penerapan metode guided conversation pada siklus II akan tetap diterapkan untuk mendapatkan peningkatan yang lebih baik.

2) Pada siklus II, metode guided conversation diterapkan, 24 orang ( $66,66 \%$ ) pada kategori yang sangat baik, $A=(80-100)$, 11 orang $(30,55 \%)$ pada kategori baik, $\mathrm{B}=(70-79), 1$ orang ( $2,77 \%)$ pada kategori nilai cukup $\mathrm{C}=(57-69)$

3) Selanjutnya uraian nilai tersebut dapat menunjukkan telah terjadi peningkatan kemampuan berbicara dengan penerapan metode guided conversation pada siklus II.

2. Mekanisme penerapan metode guided conversation dilakukan dengan :

a. Menyiapkan materi pembelajaran yang mendukung kemampuan berbicara talks as interaction pada departemen tata graha

b. Menyiapkan topik dan situasi percakapan pada pratindakan, , siklus I dan siklus II

c. Membagi mahasiswa dalam group yang akan memerankan peran sebagai housekeeping order taker, pramugraha dan tamu

d. Memberikan motivasi pada saat proses belajar mengajar

e. Melakukan (reinforcement)

penguatan berupa pengulangan materi, praktik, dan latihan interview.

f. Penguasaan pengetahuan dan keterampilan dalam bidang perhotelan khususnya pada depatemen tata graha sangat mendukung dan memberikan penguatan terhadap peningkatan keterampilan berbicara talks as interaction.

\section{Saran}

Berdasarkan hasil penelitian yang menunjukkan adanya peningkatan kemampuan berbicara talks as interactiondapat dikemukakan beberapa saran sebagai berikut :

1. Dosen bahasa Inggris

Dalam proses pembelajaran bahasa Inggris hendaknya disusun beberapa model dan teknik pembelajaran yang dikembangkan sesuai dengan perkembangan ilmu pariwisata dan perhotelan, serta mengadakan study visit ke beberapa hotel untuk melihat perkembangan dunia industri sehingga bahan ajar dapat dikembangkan sesuai dengan kebutuhan.

2. Mahasiswa

Penerapan metode guided conversation harus tetap diterapkan semaksimal mungkin terutama terhadap penguasaan bahasa Inggris Profesi agar hasil yang diperoleh lebih meningkat.

3. Bagi peneliti selanjutnya

Penelitian ini sangat memungkinkan untuk menghasilkan model evaluasi yang efektif dalam pembelajaran BIP apabila dilakukannya penelitian lanjutan guna menyempurnakan penelitian ini.

\section{DAFTAR PUSTAKA}

Anggreni, Yunik. 2016. "Peningkatan Keterampilan Berbicara Bahasa Inggris Talks As Transaction Melalui Guided Conversation Pada Mahasiswa Perhotelan, STIPAR Triatma Jaya " (Tesis). Denpasar. Universitas Udayana

Anggayana, I. W. A., \& Sari, N. L. K. J. P. (2018). Kemampuan Berbicara Bahasa Inggris Mahasiswa Akomodasi Perhotelan: sebuah 
Kajian Fonologi. Jurnal Manajemen Pelayanan Hotel, 1(1), 8-14.

Bogdan, Robert C. and Sari Knopp Biklen. 1992. Qualitative Research for Education :An Introduction to Theory and Methods ( $2^{\text {nd }} \mathrm{Ed}$ ). Boston : Allyn and Bacon.

Brown, G., Anderson, A., Shilcock, R., \& Yule, G. 1994. Teaching Talk : Strategies for Production and Assessment. Cambridge. Cambridge University Press.

Brown, H. Douglas. 2000. Principles of Language Learning and Teaching. $4^{\text {th }}$ Ed. New York : Longman.

Brown, H. Douglas 2001. Teaching by Principles : An Interactive Approach to Language to Language Pedagogy. $2^{\text {nd }}$ Ed. New York : Addison Wesley Longmann.

Burn, Anne. 1999. Collaboration Action Research For English Teacher. Cambridge : Cambridge University Press.

Harmer, Jeremy. 2001. Technique and Principles in Language Teaching $2^{N D}$. UK : Oxford University Press.

Hewings, Martin .1999. Advance Grammar In Use. New York : Cambridge University Press

Hughes, Arthur. 1989, 2003. Testing for Language Teachers. $2^{\text {nd }}$ ed. Cambridge: Cambridge University Press.

Kusumaningsih, Citra. 2012. The effectiveness of Communicative Group Activity In Teaching Speaking Viewed on Students'Risk Taking. ( An Experimental Study At The Second Semester Students of STKIP Pontianak At Academik Year 2011/2012. Pontianak : Referensi.

Leech, Geoffery. 2006. Glossary of Englsih Grammar: Edinburgh United Kingdom: Edinburgh University Press.

Lindawati, N. P., Asriyani, R., \& Anggayana, I. W. A. (2019). MODEL KOOPERATIF THINKPAIR-SHARE DALAM MENINGKATKAN KEMAMPUAN MENULIS KARANGAN DIALOG
BAHASA INGGRIS MAHASISWA AKADEMI KOMUNITAS MANAJEMEN PERHOTELAN INDONESIA. LITERA: Jurnal Litera Bahasa Dan Sastra, 4(1).

Mey, Jacob L. 2001. Pragmatics: An Introduction. Australia: Blackwell Publishing.

McCarthy, Michael.2000. Discourse Analysis For Language Teachers. United Kingdom : Cambridge University Press

Oxford Learner's Pocket Dictionary. 2008. New York : Oxford University Press

Pratiwi, Ida Ayu Ekayudha. 2012. " Peningkatan Keterampilan Berbicara dengan Metode Debat Plus dalam Proses Pembelajaran Bahasa Inggris pada Siswa Kelas XI IPA Pariwisata Kertha Wisata “ Denpasar. Universitas Udayana

Purwanto. 2010. Metode Penelitian Kuantitatif: untuk Psikologi dan Pendidikan. Yogyakarta: Pustaka Belajar.

Richard, Jack C and Rodgers, Theodore S. 1986, 1999. Approaches and Methods in Language Teaching. A Description and Analysis. USA : Cambridge University Press

Richards, Jack C. 2008. Teaching Listening and Speaking from Theory to Practice. USA : Cambrigde University.

Sadli, Hasan. 1989. Kamus InggrisIndonesia, Indonesia- Inggris. Jakarta.

Sugiyono. 2011. Metode Penelitian Kuantitatif Kualitatif dan $R \& D$. Bandung: Alfabeta.

Tarigan, Henry Guntur. 1981, Berbicara Sebagai Suatu Keterampilan Berbahasa, Bandung: Penerbit Angkasa. 